\title{
INTERNET, REDES SOCIALES Y JUICIOS PARALELOS: UN VIEJO CONOCIDO EN UN NUEVO ESCENARIO
}

\author{
PERE SIMON CASTELLANO
}


SUMARIO

I. INTRODUCCIÓN: LOS DERECHOS EN LA ERA DIGITAL. II. LA PROBLEMÁTICA DE LOS JUICIOS PARALELOS: TRES DÉCADAS DE DEBATE. 1. JUICIOS PARALELOS, LIBERTADES INFORMATIVAS Y PRINCIPIO DE PUBLICIDAD DE LAS ACTUACIONES PROCESALES; a) Durante la instrucción; b) En el juicio oral; c) Publicación y crítica de la resolución judicial. 2. EFECTOS DE LA DESINFORMACIÓN SOBRE LOS DERECHOS INDIVIDUALES Y SOBRE EL PROCESO. III. JUICIOS PARALELOS Y REDES SOCIALES: EL CASO DE LA MANADA. 1. EL TRATAMIENTO INFORMATIVO; a) Medios analógicos y programas televisivos; b) Medios digitales y redes sociales. 2. EFECTOS DE LA DESINFORMACIÓN EN INTERNET SOBRE LOS DERECHOS INDIVIDUALES. IV. CONCLUSIONES. 


\title{
INTERNET, REDES SOCIALES Y JUICIOS PARALELOS: UN VIEJO CONOCIDO EN UN NUEVO ESCENARIO
}

\author{
PERE SIMON CASTELLANO ${ }^{1}$ \\ Profesor Contratado Doctor de Derecho Constitucional \\ Universidad Internacional de la Rioja UNIR
}

\section{INTRODUCCIÓN: LOS DERECHOS EN LA ERA DIGITAL}

Con la irrupción de Internet y las más modernas nuevas tecnologías, nuestra sociedad ha experimentado cambios vertiginosos en un lapso de tiempo relativamente corto. Desde el derecho, así como desde otros campos del conocimiento - la sociología, la antropología, la comunicación periodística, la ciencia política, etc.—, se ha estudiado el impacto y la evolución de esas nuevas tecnologías y, más concretamente, el nacimiento de un nuevo paradigma comunicativo, cuya arquitectura en red ha puesto en jaque algunas de las soluciones o reglas jurídicas que operaban sin problemas en el mundo analógico ${ }^{2}$. Esa nueva realidad implica también escuchar la voz de aquellos que juegan en las fronteras de la ofensa, el menosprecio y el insulto.

Profesor Contratado Doctor de Derecho Constitucional. Facultad de Derecho, Universidad Internacional de la Rioja UNIR, Avda. de la Paz, 137, Logroño, La Rioja. Email: pere.simon@unir.net

El autor quiere agradecer sinceramente al Dr. Alfredo Abadías Selma, de la Universidad Internacional de la Rioja UNIR, por sus comentarios y sugerencias. El trabajo refleja las conclusiones de ese debate e incorpora buena parte de las consideraciones, muy atinadas, que este formuló. Sin embargo, todos los errores que puedan encontrarse son de nuestra exclusiva responsabilidad.

2 En esa misma dirección Pérez Luño señala que «en el horizonte tecnológico del presente, muchos de los problemas y de las soluciones jurídicas tradicionales aparecen irremediablemente caducos. Esa nueva situación impele al pensamiento jurídico y a la reflexión sobre los derechos a diseñar nuevos instrumentos de análisis y marcos conceptuales prontos para adaptarse a las exigencias de una sociedad en transformación». Pérez Luño, A. E. (2014). «Los derechos humanos ante las nuevas tecnologías», en Pérez Luño, A. E. (ed.), Nuevas tecnologías y derechos humanos, Valencia, Tirant lo Blanch, 17. 
Sin pretensión alguna de caer en posturas apocalípticas o integradas, siguiendo la celebre distinción que popularizó Umberto $\mathrm{Eco}^{3}$, la realidad requiere una lectura necesariamente ambivalente de la situación actual; o lo que es lo mismo, aceptar los efectos positivos y negativos de la transformación digital en relación con el ejercicio de los derechos y libertades fundamentales. Lo que bajo ningún concepto debe ser interpretado como una renuncia a tratar de mitigar los efectos perjudiciales conectados a las transformaciones que ese nuevo modelo comunicativo trae consigo aparejadas.

Lo cierto es que muchos han sido los hitos tecnológicos acontecidos durante las dos últimas décadas, entre los que destaca, sin lugar a duda, la apertura del proceso de comunicación pública ${ }^{4}$. Me refiero a una nueva extensión de las libertades informativas en el contexto digital, en el que no existe jerarquía, puesto que la información viaja y se comparte de forma horizontal y multidireccional; a escala global, sin fronteras, reduciendo las posibilidades de censura previa; con una ilimitada capacidad de almacenamiento; y con instrumentos técnicos, como los motores de búsqueda web, que permiten encontrar aquello se busca con relativa facilidad. Si, finalmente, sumamos a la ecuación la universalización en el acceso a Internet, nos queda un escenario muy proclive o favorable para el ejercicio de la libertad de expresión ${ }^{5}$.

Sin embargo, no son pocos los riesgos que, para ese mismo derecho ${ }^{6}$ y para otros, entrañan las nuevas tecnologías. Quizás el mejor ejemplo de esto es la mayor difusión

3 Se diferencian fundamentalmente dos actitudes radicalmente opuestas: los «apocalípticos» que defienden que los usos de las nuevas tecnologías tienden a provocar un impacto severo y perverso sobre el hombre masa, y los «integrados» optimistas en relación con las consecuencias de la generalización del acceso y uso de estas. Sobre esa clasificación véase Eco, U. (2004). Apocalípticos e integrados, Barcelona, Debolsillo, 74-80.

4 Un estudio exhaustivo de los efectos y transformaciones de las nuevas tecnologías en el proceso de comunicación pública puede encontrarse en Castells Olivan, M. (2009). Comunicación y Poder, Barcelona, Alianza Editorial. Véase también Corredoira Alfonso, L. (dir.) y Cotino Hueso, L. (dir.). (2013). Libertad de expresión e información en Internet: amenazas y protección de los derechos personales, Madrid, Centro de Estudios Políticos y Constitucionales.

5 No sólo para el ciudadano, que puede acceder y comunicarse sin dificultades en Internet, sino también para los profesionales de la información, puesto que Internet ofrece dos ingredientes largamente buscados por la prensa: la inmediatez y la disponibilidad de un espacio casi infinito para publicar contenidos. Sobre este particular véase Pauner Chulvi, C. (2014). «El impacto de las nuevas tecnologías en los derechos fundamentales: el reto de la privacidad en la prensa digital», en Pérez Luño, A. E. (ed.), Nuevas tecnologías..., cit., 155. Es importante en cualquier caso recordar que, aunque el ciudadano puede acceder a ese proceso de comunicación pública con cierta facilidad, eso no significa que vaya a ser «escuchado». Puede, al respecto, consultarse la obra de Hindman, M. (2009). The Myth of Digital Democracy, New Jersey-Oxford, Princeton University Press.

6 Nos referimos a la falacia que plantean las redes sociales de Internet, cuyo funcionamiento esta basado en unos algoritmos que refuerzan el individualismo y consiguen, básicamente, que el usuario encuentre sólo aquella información o contenidos que encajan con su forma de ver el mundo. El efecto es, en realidad, perverso, puesto que altera la forma de concebir nuestras relaciones sociales e incluso el modo en el que percibimos la realidad. Véase en esta misma línea Carr, R. (2017). ¿Qué está haciendo Internet con nuestras mentes? Superficiales, Barcelona, Taurus. 
que tienen los contenidos que se comparten en Internet y en las redes sociales, lo que paradójicamente lleva a que el tratamiento de estos en el ámbito penal se haga de un modo que tiende precisamente a restringir la efectividad de la libertad de expresión ${ }^{7}$. Esas mismas facilidades para compartir contenidos combinadas con la capacidad de almacenamiento han situado en la encrucijada a otros derechos como la propiedad intelectual o los derechos conectados con la dignidad humana y el libre desarrollo de la personalidad, que se ven más expuestos en un escenario en el que muchas veces los ciudadanos tienden a confundir las redes sociales con la barra del bar ${ }^{8}$.

Con todo, en ciertas ocasiones y en casos concretos, los principios que permiten resolver los conflictos entre los derechos en la realidad material se pueden exportar, sin mayores problemas, al entorno online. Sirva como ejemplo la respuesta penal frente a expresiones vertidas en redes sociales o foros de Internet, cuya solución no requiere necesariamente inventar respuestas nuevas, ni tampoco esperar la intervención del legislador, sino que más bien pasa por aplicar, cuando no adaptar, a dicho medio, los principios que operan en el mundo analógico, por contraposición al entorno digital ${ }^{9}$.

Esa adaptación de los principios y conceptos jurídicos al mundo digital no ha sido siempre, empero, del todo fácil o suficiente. Así, en determinadas circunstancias, ha requerido directamente la intervención legislativa y, en este ámbito, cabe recordar que la tecnología siempre va por delante del legislador, cuya actividad, de entrada, es más bien reactiva y no proactiva, salvo contadas excepciones ${ }^{10}$. Ese es el caso del catálogo de derechos digitales ${ }^{11}$ que incorpora la Ley Orgánica 3/2018, de 5 de

7 Para un análisis pormenorizado de este peculiar efecto puede encontrarse en Boix Palop, A. (2016). «La construcción de los límites a la libertad de expresión». Revista de Estudios Políticos, $173,66$.

8 Sobre la creciente tendencia lesiva de los derechos de la personalidad, véase Vázquez de Castro, L. M. (dir). (2019). Internet y los derechos de la personalidad. La protección jurídica desde el punto de vista del Derecho Privado, Valencia, Tirant lo Blanch.

9 La adaptación es necesaria puesto que hay que tener en cuenta las características propias del canal en el que se produce esa comunicación, ya sea para calificar la conducta o para valorar sus efectos sobre los derechos en juego. Como señala Cabellos Espiérrez, «una conducta realizada fuera de internet no ve variar su calificación ni su esencia cuando es realizada dentro de este medio, pero no es menos cierto que en determinados ámbitos de internet, como es el caso de las redes sociales, las características de estas y de los mensajes en ellas emitidos pueden ser relevantes a la hora de calificar la conducta». Cabellos Espiérrez, M. A. (2018). «Opinar, enaltecer, humillar: respuesta penal e interpretación constitucionalmente adecuada en el tiempo de las redes sociales». Revista Española de Derecho Constitucional, 112, 47.

10 Los constituyentes establecieron un claro mandato al legislador en el artículo 18.4 de la Carta Magna, avanzándose en cierto modo a los peligros que entraña el avance tecnológico, si bien es cierto que este precepto recibió una clara influencia de la Constitución portuguesa, sólo dos años anterior a la española. Un mandato cuyo desarrollo ha permitido incluso articular una respuesta en tiempos de pandemia y crisis sanitaria. Véase al respecto Rodríguez Ayuso, J. F. (2020). Privacidad y coronavirus. Aspectos esenciales, Madrid, Dykinson, 28 y ss.

11 No pretendemos aquí hacer una valoración sobre la peculiar técnica legislativa que lleva a regular esta cuestión a través de un título específico de una Ley Orgánica dedicada a la protección de datos. El título décimo de la LOPDGDD, que enumera una serie de derechos digitales sin apuntar 
diciembre, de Protección de Datos Personales y garantía de los derechos digitales (en adelante, LOPDGDD), entre los que se enumera, por ejemplo, el derecho a la desconexión digital en el ámbito laboral, que protege el tiempo de descanso, permisos y vacaciones de los trabajadores, así como su intimidad personal y familiar. No obstante, en otras ocasiones, ha sido la doctrina jurisprudencial la que se ha avanzado al legislador y ha tenido que intervenir, como en el caso del derecho a la protección de datos $^{12}$ y también en el paradigmático caso del llamado derecho al olvido digital ${ }^{13}$.

La mera adaptación de los principios jurídicos a la realidad digital resulta entonces, en la mayoría de los supuestos, insuficiente, más aún cuando el canal comunicativo reviste características tan relevantes como el efecto multiplicador y exponencial que tiene cualquier acción o expresión emitida en el ciberespacio ${ }^{14}$. Las transformaciones fruto del impacto de las nuevas tecnologías sobre la realidad social se han proyectado sobre el mismo concepto y definición de Derecho, y se reflejan también en el significado, función y garantía de las libertades ${ }^{15}$. En este escenario complejo aparecen, además, los llamados juicios paralelos, una vieja lacra que ha acompañado a la práctica judicial con una intensidad creciente a lo largo de las tres últimas déca-

garantía alguna para su cumplimiento efectivo ni mecanismos de protección, ha sido aplaudido desde visiones más utilitaristas, pragmáticas, que tratan de dar una respuesta rápida a los retos que presenta la sociedad digital. Véase sobre los nuevos derechos digitales la valiosa aportación de Rallo Lombarte, A. (2019). «Del derecho a la protección de datos a la garantía de nuevos derechos digitales», en Rallo Lombarte, A. (dir.) Tratado de protección de datos. Actualizado con la ley orgánica 3/2018, de 5 de diciembre, de protección de datos personales y garantía de los derechos digitales, Valencia, Tirant lo Blanch, 23-52.

12 Véanse por todas las SSTC 254/1993, de 20 de julio y la 290/2000, de 30 de noviembre.

13 Sentencia del Tribunal de Justicia de la Unión Europea, Google Spain, S.L. y Google Inc. vs. Agencia Española de Protección de Datos (AEPD) y Mario Costeja González, ECLI:EU:C:2014:317. Un estudio exhaustivo de la sentencia puede encontrarse en Berrocal Lanzarot, A. I. (2017). Derecho de supresión de datos o derecho al olvido, Madrid, Editorial Reus, 119-169. Sobre el nacimiento y reconocimiento del llamado derecho al olvido digital véanse por todos Simón Castellano, P. (2012). El régimen constitucional del derecho al olvido digital, Valencia, Tirant lo Blanch; Simón Castellano, P. (2015). El reconocimiento del derecho al olvido digital en España y en la UE, Barcelona, Bosch. Un estudio actualizado sobre el tema puede encontrarse en Cobacho López, A. (2019). «Reflexiones en torno a la última actualización del derecho al olvido digital». Revista de Derecho Político, 104, 198-227.

14 El Tribunal Supremo se ha referido a la «multiplicación de la publicidad que generan los motores de búsqueda de Internet» como un efecto nocivo para los derechos de la personalidad. El hecho que cualquier internauta pueda obtener un perfil completo de una persona, por el mero hecho de hacer una búsqueda con su nombre y apellidos en un buscador web, en el que además aparezcan informaciones obsoletas sobre hechos ya remotos, entraña per se un grave potencial dañoso para su honor y su intimidad, y un «efecto distorsionador de la percepción que de esta persona tengan los demás conciudadanos». STS 545/2015, 15 de octubre de 2015, FJ 7.

15 Véase en esta misma dirección los trabajos de Pérez Luño, A. E. (2016). «Nuevo derecho, nuevos derechos». Anuario de filosofía del derecho, 32, 15-36; Pérez Luño, A. E. (2014). «Los derechos humanos ante las nuevas tecnologías..., cit., 17 y ss; Cotino Hueso, L. (2018). «La necesaria actualización de los derechos fundamentales como derechos digitales ante el desarrollo de internet y las nuevas tecnologías», en Pendás García, B. (dir.), España constitucional (1978-2018): trayectorias y perspectivas, Vol. 3, Tomo 3, Madrid, Centro de Estudios Políticos y Constitucionales, 2347-2361. 
das, y que se ha canalizado tradicionalmente a través de la televisión y los programas de la llamada telebasura ${ }^{16}$.

La voz juicio paralelo ha sido utilizada por la doctrina de forma indistinta a la expresión juicio mediático. De hecho, disponemos a día de hoy de muchas definiciones posibles ${ }^{17}$, si bien, antes de proseguir, interesa ofrecer aquí una definición que agrupe los principales rasgos o características de este tipo de «juicios»: se trata de debates que se producen en los medios de comunicación sobre una cuestión que está sub iudice, que escapan al género informativo clásico — quizás la fórmula más perversa es la tertulia televisiva-, en los que se emiten opiniones, informaciones y juicios de valor, y que contribuyen a prejuzgar la culpabilidad o inocencia del acusado ${ }^{18}$, hasta el punto de poder llegar a estigmatizarlo de por vida o, cuanto menos, en el corto plazo $^{19}$.

La hipótesis de partida sobre la que se articula y justifica este trabajo es que Internet y las redes sociales contribuyen a multiplicar los efectos de los juicios mediáticos y, por ende, también incrementan los riesgos y la intensidad de las eventuales lesiones de los derechos fundamentales del investigado. Con el fin de contrastar esa

16 Marc Carrillo ha sido una de las voces que más ha estudiado y criticado el fenómeno de este tipo de programas de entretenimiento o pseudodebate, muy presentes en los medios audiovisuales españoles. Siguiendo al autor, no puede defenderse de modo alguno que esas prácticas estén amparadas por las libertades informativas cuando se trata de «una mercancía basada en la zafiedad cultural y en la chabacanería costumbrista, protagonizada por un ejército de individuos televisivos que no pasan de ser una caterva de ociosos a la búsqueda de su minuto de gloria. Una mercancía fundada en la pura demagogia social, de un populismo carente de escrúpulos. Y ello con la aquiescencia tanto de determinados sectores de la sociedad como de algunos poderes públicos y privados que conviven cómodamente con la banalidad como categoría social de comportamiento, cosa que define para mal la media de los parámetros culturales del país». Carrillo, M. (2017). «Los juicios paralelos en derecho comparado: el caso de España», en Ovejero Puente, A. M. (ed.), Presunción de inocencia y juicios paralelos en derecho comparado, Valencia, Tirant lo Blanch, 67 y 68.

17 En tal sentido Orenes Ruiz aporta una de las definiciones más completas al referirse al juicio paralelo como «un juicio desarrollado en y por los medios, con anterioridad y simultaneidad al verdadero juicio que se celebró en los tribunales, en el que se expusieron y valoraron todo tipo de testimonios: del acusado, testigos, familiares, vecinos, autoridades, abogados, policías y expertos; en donde se formularon los más variados juicios de valor sobre el comportamiento y personalidad de los actores del proceso, y en el que se realizaron numerosas reconstrucciones de cómo sucedieron los hechos». Orenes Ruiz, J. C. (2010). «Imparcialidad judicial y juicios paralelos. Consideraciones sobre la STS de 29 de septiembre de 2010». Actualidad Jurídica Aranzadi, 810, 12-13.

18 Existe consenso doctrinal acerca de que determinadas prácticas comunicativas prejuzgan la culpabilidad o inocencia del investigado, con independencia de los efectos que esto pueda tener sobre los derechos de este. En ese sentido Juanes Peces asevera que en los juicios paralelos «se prejuzga la culpabilidad o inocencia de las personas sometidas a un proceso, en definitiva, valorando la regularidad legal y ética de su comportamiento», lo que «se convierte ante la opinión pública en una suerte de proceso en el que los medios de comunicación ejercen los papeles de fiscal y abogado defensor, determinando la inocencia o culpabilidad de los acusados (...)». Juanes Peces, A. (1999). «Los juicios paralelos: Eventual vulneración de los derechos a un proceso justo». Actualidad Jurídica Aranzadi, 378, 2-3.

19 En términos de Ferrajoli, se substituye el «rollo y la picota» por la exhibición y difamación pública del acusado. Ferrajoli, L. (2000). Derecho y razón. Teoría del garantismo penal, Madrid, Trotta, 616. 
premisa, en primer lugar, estudiaremos los efectos que tradicionalmente este tipo de juicios han tenido sobre los derechos fundamentales del encausado, cuando estos se han producido en la prensa escrita, en la radio y, muy especialmente, en la televisión. En segundo lugar, estudiaremos el caso de La Manada para explorar la influencia de Internet y las redes sociales en el nacimiento, seguimiento y retroalimentación de uno de los juicios paralelos más paradigmáticos de los últimos tiempos. Con tal fin analizaremos el tratamiento informativo durante el juicio mediático, tanto en medios de comunicación convencionales como en las redes sociales. Por último, una vez contrastada la hipótesis, ya sea mediante su refutación o confirmación, y tras contextualizar y plantear los términos del debate acerca de esta clase de juicios, formularemos propuestas constructivas sobre este mal endémico que, a pesar de haber recibido fuertes criticas doctrinales a lo largo de las últimas décadas, parece enquistarse en una sociedad que se resigna a aceptar esos juicios como algo inevitable.

\section{LA PROBLEMÁTICA DE LOS JUICIOS PARALELOS: TRES DÉCADAS DE DEBATE.}

La relación entre el Poder Judicial y los medios de comunicación social no es prima facie fácil. El derecho a la información incluye, como veremos más al detalle infra, el derecho a conocer el desarrollo de procesos penales cuya publicidad es indiscutible, por ser de interés general. Así, la información cotidiana sobre procesos penales en curso ha planteado en muchas ocasiones situaciones de conflicto en las que se pueden afectar gravemente derechos e intereses — tanto los derechos del investigado como las garantías procesales — de forma absolutamente inadmisible, puesto que el derecho a la información también conoce límites, como el necesario respeto al honor, a la vida privada y familiar — art. $18 \mathrm{CE}$ - y a la presunción de inocencia —art. $24 \mathrm{CE}$-, entre muchos otros.

La colisión entre los citados derechos requiere de la ponderación que realizan juzgados y tribunales en el caso concreto, aplicando el tradicional principio de proporcionalidad, que a su vez integra los juicios de idoneidad, necesidad y proporcionalidad en sentido estricto, esto es, atendiendo al grado de injerencia, así como el carácter y alcance del sacrificio que impone sobre los derechos o intereses afectados ${ }^{20}$. La ventaja de este esquema de decisión empleado por el TC en innumerables ocasiones es que produce soluciones ajustadas al caso, que no prejuzgan casos futuros en los que los mismos derechos o intereses vuelvan a mostrarse en conflicto, sino en la medida en que las circunstancias sean las mismas.

En el ámbito de las libertades informativas, además, ese ejercicio se realiza teniendo en cuenta la veracidad de la información y el interés público constitucionalmente

20 Véase Bernal Pulido, C. (2003). El principio de proporcionalidady los derechos fundamentales. Madrid, Centro de Estudios Políticos y Constitucionales. 
prevalente, dado el papel tan relevante y significativo que juegan las libertades informativas en pos de la formación de la opinión pública libre, necesaria en cualquier sociedad que aspire obtener el calificativo de democrática ${ }^{21}$. Se parte entonces de la posición especial que en nuestro ordenamiento ocupa la libertad de información que no sólo protege un interés individual, sino que entraña el reconocimiento y garantía de la existencia de una opinión pública libre, si bien es cierto que esa misma doctrina jurisprudencial ha relativizado el valor preferente o prevalente de este derecho, negando en cualquier caso su supremacía sobre otros derechos fundamentales ${ }^{22}$.

El interés público informativo ${ }^{23}$ sólo concurre cuando la información que se comunica es relevante para la comunidad, lo cual justifica la exigencia de que se asuman perturbaciones o molestias ocasionadas por la difusión de una determinada noticia. Se trata de un concepto jurídico indeterminado, cuya concurrencia pasa por determinar si nos encontramos ante unos hechos o circunstancias susceptibles de afectar al conjunto de los ciudadanos, que como bien señala López Calera, debe ser «diferenciado de la idea metafísica y iusnaturalista de bien común, ha de ser ante todo un valor democrático, en cuanto su definición debe estar en manos de poderes democráticamente legitimados y su realización ha de implicar la protección y la realización de un mayor número de intereses particulares» ${ }^{24}$. Con todo, nunca debe confundirse el interés público informativo con el interés del público, más cercano a la satisfacción de la curiosidad humana o ajena ${ }^{25}$.

Así las cosas, podría parecer que el conflicto sería relativamente fácil de resolver. La información sobre procesos judiciales debe ser pública y el derecho a tener acceso a la misma actúa como un binomio que garantiza, por un lado, el derecho a comunicar al público información y, por el otro, el derecho del público a recibirla. Además, como este ejercicio se lleva a cabo por parte de profesionales de la información, que cuentan con un código deontológico y conocen mejor que nadie los límites de la práctica a la que se dedican profesionalmente, los llamados juicios paralelos no deberían tener recorrido alguno.

Pero la práctica nos muestra casos concretos en los que el ejercicio periodístico dista mucho de lo comentado. En primer lugar, cabe recordar que el medio de comunicación para el que publican los periodistas, para sobrevivir, necesita audiencia ${ }^{26}$

21 Véanse por todas las SSTC 134/1999, de 15 de julio, FJ 8; 154/1999, de 14 de septiembre, FJ 9; 52/2002, de 25 de febrero, FJ 8.

22 Véase la STC 83/2002, de 22 de abril.

23 El Tribunal Supremo ha justificado el ejercicio de la crítica a las resoluciones judiciales atendiendo al interés público que resulta siempre inherente al mero ejercicio de la función jurisdiccional. Véase por todas la reciente STS 92/2018, de 19 de febrero.

24 López Calera, N. (2010). «El interés público: entre la ideología y el Derecho», Anales de la Cátedra Francisco Suárez, 44, 123-148.

25 Véanse por todas las SSTC 29/1992, de 11 de febrero, FJ 3; 134/1999, de 15 de julio, FJ 8; $115 / 2000$, de 5 de mayo, FJ 9.

26 Lo expresa muy bien Paredes Castañón cuando dice que «es evidente que el modelo de negocio de los medios de comunicación se basa, ante todo, en la captación de audiencia; por ello, el primer filtro 
—espectadores o lectores_-, lo que se hace si cabe más evidente o sangrante en los entornos digitales, en los que la clave no es tanto que te lean o te vean, sino más bien que accedan y poder generar tráfico publicitario, aunque el contenido tras el click difiera enormemente del titular ${ }^{27}$. Se trata de la cultura táctil que permite a los cibernautas satisfacer sus deseos de forma inmediata, rápida, justo en lo que se tarda en tocar la pantalla de la tablet o del móvili1 ${ }^{28}$.

En segundo lugar, la selección en la información y el modo en el que esta se presenta deriva de dos ejes que poco tienen que ver con la libertad de información: el interés periodístico del caso y el interés público ${ }^{29}$ del medio de comunicación, que nada tiene que ver con el interés público informativo al que nos referíamos anteriormente, esto es, el interés público de la información stricto sensu, que constituye un criterio clave, junto a otras garantías constitucionales, para ponderar y dar prioridad, en su caso, al derecho a la información en caso de conflicto frente a otros derechos fundamentales ${ }^{30}$.

El primer criterio, el interés periodístico, depende del modelo de negocio y de la estructura económica del medio de comunicación, y es probablemente el más relevante en la comunicación que se hace de la información judicial, tal y como ha señalado certeramente Jewkes ${ }^{31}$, que además detalla ciertos factores que hacen que una noticia en materia penal sea más o menos interesante. Tales factores son la existencia de un plazo-límite, lo que incorpora dramatismo al asunto, la imprevisibilidad del resultado, la simplicidad de lo que se comunica, el carácter individualizable de los protagonistas, la permanencia del riesgo en el futuro, las connotaciones sexuales, la fama o estatus elevado de los protagonistas, la proximidad, en el espacio o tiempo del delito, la concurrencia de violencia, la espectacularidad visual, y la presencia de menores $^{32}$.

de selección es la capacidad de la noticia para suscitar la atención del público. Me refiero, principalmente, a los medios privados, si bien es necesario señalar que los medios públicos cada vez se aproximan más a aquellos en la forma de gestionar la información». Paredes Castañón, J. M. (2019). «La interacción entre los medios de comunicación social y la política criminal en las democracias de masas». Teoría y Derecho, Revista de Pensamiento Jurídico, 24, 93-114.

27 Se evidencia de forma paradigmática en el caso de los medios deportivos online. Véase sobre este particular y, también, sobre los problemas específicos en la moderación de contenidos, el trabajo de López González, H. y Guerrero Solé, F. (2014). «Moderación de la conversación en medios online. El caso del diario Marca». El profesional de la información, 23 (1), 58-64.

28 Sobre los efectos del sistema touch o «cultura táctil» véase Abadías Selma, A. (2017). La violencia filio-parental y la reinserción del menor infractor, Barcelona, JM Bosch Editor, 80.

29 Jewkes, Y. (2015). Media E Crime, Los Ángeles, Londres, Nueva Delhi, Singapur, Washington, Ed. Sage, 44-48.

30 La relevancia pública de los hechos actúa como criterio esencial a la hora de ponderar las libertades informativas en conflicto con otros derechos. Sobre este tema véase por todas la STC 139/2007, de 4 de junio, FJ 7 y 8.

31 Ibídem, 49-68.

32 Estos mismos factores son estudiados en profundidad en el trabajo de Paredes Castañón, J. M. (2019). «La interacción entre los medios..., cit., 99-100. 
La propia naturaleza de este tipo de factores nos retrotrae necesariamente a los primeros juicios paralelos celebrados en nuestro país, a principios de la década de los años 90, todos ellos casos que reúnen buena parte de los factores mencionados. Quizás el caso más mediático de la época es el relativo al descubrimiento de los cuerpos sin vida de tres niñas de Alcácer, en 1992, que fueron secuestradas, violadas, torturadas y finalmente asesinadas, cuyo seguimiento por parte de determinadas cadenas de televisión generó fuertes críticas procedentes tanto del ámbito judicial como de los propios profesionales de la información. Se trata de un caso paradigmático, aunque no el único de la época ${ }^{33}$, en el que concurren violencia, espectacularidad visual, presencia de menores de edad, connotaciones sexuales y sobre el cual aún hoy en día circulan teorías conspirativas $^{34}$. El tratamiento televisivo por parte de los programas «Esta noche cruzamos el Mississippi» de Tele 5 y «Jui d'Alcàsser» de Canal 9, que fueron emitidos en 1995 y 1997 respectivamente, fue absolutamente deleznable ${ }^{35}$. De hecho, en el caso del programa de Canal 9 intervinieron el padre de una de las víctimas y un «criminólogo» que posteriormente fueron condenados por delitos de injurias y calumnias, con la responsabilidad civil solidaria de la cadena ${ }^{36}$. Sin embargo, la condena llegó muy tarde — en el año 2009- como para evitar otras declaraciones que se produjeron en el período de tiempo en el que el caso ocupó el prime time televisivo.

Se observa, así, que aquellos casos sub iudice que agrupan una serie de factores están prácticamente predeterminados a convertirse en un claro reclamo para la audiencia. Es un patrón común que se observa desde el juicio de Alcácer hasta el juicio de la Manada ${ }^{37}$.

33 El caso Arny en esa misma época tuvo también una gran repercusión y seguimiento, al tratarse de unas supuestas actividades de prostitución de menores que se produjeron en un bar gay de Sevilla y en el que estaban implicados a una larga lista de hombres entre los que destacaban varias personalidades públicas, como Jorge Cadaval y Jesús Vázquez, que con el tiempo pudieron rehacer su vida. Véase la portada del diario ABC del 22 de marzo de 1996: https://www.abc.es/archivo/periodicos/abcsevilla-19960322.html (última consulta el 1 de abril de 2020).

34 Buena muestra de ello es la Serie Documental titulada «El caso Alcàsser» producida y disponible en Netflix en el año 2019, con «nuevas entrevistas» y una «revisión actualizada de las pruebas» y teorías sobre el caso. https://www.netflix.com/es/title/80213115 (última consulta el 1 de abril de 2020).

35 En el caso de Canal 9 se montó un dispositivo especial para la retransmisión del juicio en directo durante el cual se calificó el juicio de «circo»; se afirmó que el Fiscal «chochea», «que debe hacer todo lo necesario para buscar la verdad y ha hecho lo contrario», que «miente»; que los forenses «son unos ineptos, son personajes de tebeo», que «han mentido» $\mathrm{y}$ «cometido perjurio»; que la «sentencia estaba puesta con anterioridad al juicio»; que miembros de la Guardia Civil habían ocultado y destruido pruebas, acusándolos de estúpidos, mentirosos y torpes. Véase sobre este particular la Sentencia del Juzgado de lo Penal núm. 2 de Valencia, núm. 275/2009, de 11 de julio de 2009.

36 Ibidem.

37 Desde el caso de las niñas de Alcácer muchos han sido los juicios paralelos celebrados en los medios de comunicación en nuestro país, lo que pone de manifiesto que estamos ante una patología informativa consolidada. Sirvan como ejemplo la operación Karlos; el caso Malaya; caso Farruquito, caso Diego Pastrana, caso Ortega Cano, caso Marta del Castillo; caso Francisco Camps; operación Galgo; caso Urdangarín; entre muchos otros. 
El segundo criterio, el interés público del medio de comunicación, está más vinculado a la estructura política del medio de comunicación, es decir, conecta los criterios de elección de la información a comunicar con la politización partidista del medio. El interés de los medios de comunicación a la hora de seleccionar la información - tanto por lo que se refiere a la selección en sí, como a la forma en la que esta se presenta - no responde necesariamente ni es exclusivamente fruto de una visión utilitaria o comercial, sino que muchas veces es la consecuencia de aplicar criterios políticos. La ideología de los directivos o accionistas de las empresas de comunicación, las alianzas entre los grupos empresariales e incluso la ideología de los propios periodistas, es un factor que está muy presente en la selección de la información y en su puesta en escena. Este criterio, que afecta a muchísimas publicaciones de los medios de comunicación tradicionales, también se extiende sobre la información relativa a procesos judiciales. Buen ejemplo de ello es el seguimiento del juicio del procés ${ }^{38}$ o del caso Bárcenas, entre otros.

La realidad práctica de determinados medios de comunicación social, y especialmente en los casos de programas dedicados al cotilleo, show o espectáculo, contrasta entonces con los criterios que deberían inspirar el proceso comunicativo de lo que acontece en las salas de justicia. Como hemos visto, en la práctica periodística, interés periodístico e interés público del medio de comunicación constituyen los criterios básicos que condicionaran la selección de noticias y mensajes, la construcción del discurso, la forma de narrar los hechos y la interpretación de estos de un modo determinado. Todo ello influye de forma decisiva en la imagen o realidad que el público se formará sobre la actuación judicial y los hechos del caso ${ }^{39}$.

Una vez contextualizada la razón de ser de los juicios paralelos, esto es, el choque entre la naturaleza de los criterios e intereses de los medios de comunicación social y los principios que deberían guiar tanto la publicidad del proceso penal como la crítica

38 Sobre este caso concreto se expresa con contundencia Quintero Olivares cuando afirma que «la meta del juicio paralelo orquestado por los medios de comunicación de Cataluña, con programas diarios, ha sido transmitir la idea de que la Sentencia generaría dos verdades diferentes, la «libre» y la judicial, todo en nombre de la libertad de información, pero con el abierto propósito de presionar al Gobierno y al Tribunal Supremo (mezclar ambos es parte de la estrategia del independentismo). Otro interés sistemáticamente pisoteado por los medios de comunicación catalanistas es el derecho del ciudadano a recibir información objetiva, pero esa es otra desgracia endémica que padece Cataluña y no se limita al problema de la sentencia. El objetivo esencial de toda la información manipulada o sesgada no era otro que preparar la descalificación global del fallo y, de paso, de la «justicia española»». Quintero Olivares, G. (2019). «La Sentencia catalana y la desobediencia». Teoría y Derecho, Revista de Pensamiento Jurídico, 26, 114.

39 Surette enumera los principales recursos u operaciones semióticas a través de las que los medios de comunicación construyen y manipulan la realidad de los problemas político-criminales. Lo hacen mediante la selección de sujetos con legitimad para comunicar y opinar; la creación de narraciones acerca del caso o problema que se comunica; la vinculación a marcos cognitivos preexistentes; finalmente, con la conversión selectiva del caso en signo. Surette, R. (2011). Media, Crime and Criminal Justice, Belmont, Wadsworth Publishing Co, 34-44. Véase también Paredes Castañón, J. M. (2019). «La interacción entre los medios..., cit., 103-106. 
de los problemas político-criminales, veamos cual es la afectación concreta de los bienes jurídico-constitucionales en juego.

\section{JUICIOS PARALELOS, LIBERTADES INFORMATIVAS Y PRINCIPIO DE PUBLICIDAD DE LAS ACTUACIONES PROCESALES.}

\section{a) Durante la instrucción}

En la fase sumarial predomina el secreto de las actuaciones y diligencias ${ }^{40}$ —art. 301 LECrim — y la publicidad para las partes ${ }^{41}$ — art. 302.1 LECrim —, a excepción que el Juez de instrucción acuerde, total o parcialmente, el secreto para las partes de acuerdo con los requisitos que establece el artículo 302.2 LECrim $^{42}$. Por lo tanto, la regla general que rige en la fase de investigación es el secreto externo ${ }^{43}$ del proceso y la publicidad interna para las partes. Tal regulación se extiende hasta la apertura del juicio oral, y admite excepciones que no afectan al secreto externo del proceso.

Cuando hablamos de secreto externo hacemos referencia a que las actuaciones y diligencias sumariales son secretas para todas las personas que no tienen la consideración de parte procesal. Es decir, el público, en sentido general, no puede acceder a las informaciones ni a los expedientes de las investigaciones en curso que dirige el instructor. Tampoco es accesible, claro está, para los medios de comunicación que se encargan de difundir y explicar la noticia. El principal fundamento del secreto en la fase de instrucción se encuentra en el interés de garantizar el éxito de la investiga-

40 «Las diligencias del sumario serán secretas hasta que se abra el juicio oral, con las excepciones determinadas en la presente Ley. El Abogado o Procurador de cualquiera de las partes que revelare indebidamente el secreto del sumario, será corregido con multa de 250 a 2.500 pesetas. En la misma multa incurrirá cualquier otra persona que no siendo funcionario público cometa la misma falta. El funcionario público, en el caso de los párrafos anteriores, incurrirá en la responsabilidad que el Código Penal señale en su lugar respectivo». Artículo 301 LECrim.

41 «Las partes personadas podrán tomar conocimiento de las actuaciones e intervenir en todas las diligencias del procedimiento». Artículo 302.1 LECrim.

42 «(...) si el delito fuere público, podrá el Juez de instrucción, a propuesta del Ministerio fiscal, de cualquiera de las partes personadas o de oficio, declararlo, mediante auto, total o parcialmente secreto para todas las partes personadas, por tiempo no superior a un mes y debiendo alzarse necesariamente el secreto con diez días de antelación a la conclusión del sumario». Artículo 302.2 LECrim.

43 La LECrim no contempla expresamente el secreto para la fase previa al juicio oral en el llamado procedimiento abreviado. No obstante, la doctrina ha entendido que la regla general es la misma para el procedimiento abreviado, esencialmente, porque el art. 758 de la LECrim prevé que el enjuiciamiento de los delitos vía procedimiento abreviado se acomodará a las normas comunes de la LECrim. Véase, por todos, Otero González, M. P. (1999). Protección penal del secreto sumarial y juicios paralelos. Madrid, Centro de Estudios Ramón Areces, Madrid, 1999, 82-86. 
ción ${ }^{44}$, impidiendo comunicaciones no deseadas que puedan provocar la destrucción o manipulación de las fuentes de prueba o una eventual fuga de los que han participado en la comisión del hecho punible.

Sin embargo, el fundamento constitucional del secreto sumarial no se agota en los motivos encaminados a la segura represión del delito y como garantía del valor constitucional del interés de la Justicia — que la CE recoge como valor jurídico en el art. 1.1-, sino que también pretende garantizar la debida salvaguarda del honor de los afectados por el proceso penal, que son, esencialmente, la víctima y el investigado. La protección del honor es otra de las razones jurídicas que inspiran el secreto en la fase de investigación, y que lo hacen objetivamente deseable. Con ello se evita que las personas sometidas a investigación sufran más perjuicios de los que son estrictamente necesarios $^{45}$.

En definitiva, el secreto sumarial se plantea como una figura procesal singular que se erige como una verdadera excepción a la garantía institucional de publicidad que contiene el art. 120.1 de la CE. Con todo, no existe óbice alguno para declarar que «el proceso penal $[. .$.$] puede tener una fase sumaria amparada por el secreto y en$ cuanto tal limitativa de la publicidad y de la libertad ${ }^{46}$.

Las filtraciones del sumario proyectan sus efectos en la tribuna pública y contribuyen o fomentan los juicios paralelos. Ciertamente, la divulgación de la información de los expedientes sumariales del proceso penal puede ocasionar severas consecuencias para el buen nombre del investigado y la víctima, y a su vez, no tener ninguna consecuencia positiva para la opinión pública ${ }^{47}$. Como reacción, se prevé la posibilidad de sancionar penalmente a los infractores —artículos 417, 418 y 466 del Código

44 Un argumento decimonónico que ya estaba presente en los trabajos para la redacción de la Ley de Enjuiciamiento Criminal de 1882.

45 En relación con ello la doctrina ha señalado que «el secreto de las actuaciones instructorias ayuda a conservar el honor y el buen nombre del acusado (garantizados en el art. 18.1 de la CE) y lo aleja del daño que puede producir la publicidad (principalmente si es propagada por algún medio de comunicación social: televisión, radio, prensa, etc.), por lo que así entendido es un bien para el encausado». CondePumpido Ferreiro, C. (dir.). (2004). Comentarios a la ley de Enjuiciamiento Criminal y otras leyes del proceso penal: (Jurado, Extradición Pasiva, Habeas Corpus y Asistencia Jurídica Gratuita), volumen II, Valencia, Tirant lo Blanch, 1287.

46 STC 13/1985, de 31 de enero, FJ 3.

47 «QQué aporta a una opinión pública madura y libre el dato — cuya divulgación la ley prohíbede que alguien está siendo investigado porque ha sido objeto de una denuncia, si luego esa persona va a ser judicialmente declarada libre de reproche porque la denuncia resultó infundada? Además de poner en entredicho el honor de tales personas, ¿no es mayor el daño que el beneficio que se deriva de esas informaciones para la opinión pública, a la que se alimenta de prejuicios y a la que se induce a errores? Puestos a ponderar el daño al honor del sujeto investigado y el beneficio para la opinión pública como justificante de la posible prioridad del derecho a informar, ¿no habría que aquilatar un poco mejor si tales beneficios existen o si no serán más bien perjuicios?». García Amado, J. A. (2005). «Tres sentencias del Tribunal Constitucional. O de cuán fácil es la veracidad periodística y qué liviano el honor de los particulares», pág. 12, disponible en Internet: http://www.geocities.ws/jagamado/tressentenciasdef.htm (última consulta el 24 de junio de 2020). 
Penal_-, aunque tal posibilidad sólo está prevista respecto a informaciones sobre actuaciones procesales declaradas secretas por la autoridad judicial, esto es, en relación con el secreto interno. El propio art. 301 de la LECrim diferencia las consecuencias jurídicas derivadas de la infracción del deber de secreto del sumario en función del autor que las comete. En caso de que sean funcionarios o autoridades estos incurrirán en responsabilidad penal y multa disciplinaria; mientras que para los abogados y procuradores sólo se prevé la última posibilidad. El bien jurídico protegido es el buen funcionamiento de la justicia ${ }^{48}$ mediante el consecuente deber de sigilo de los funcionarios ${ }^{49}$. Además de la responsabilidad criminal, cabe también la responsabilidad disciplinaria de los funcionarios públicos por la revelación de las informaciones del sumario que está bajo secreto de acuerdo con los artículos 396, 417.12 y 420 de la LOPJ.

Más allá de la disparidad de consecuencias en función del autor, lo cierto es que el tipo del artículo 446 CP sólo es aplicable en caso de secreto interno expresamente decretado por los tribunales. Y para más inri, la responsabilidad penal y disciplinaria es prácticamente imposible de alcanzar en la práctica. Esencialmente, porque el secreto profesional del periodista ${ }^{50}$, que encuentra su razón jurídico-constitucional en el art. 20.1.d) y en el 24.2 de la CE, dificulta notoriamente la investigación de la filtración. Las dificultades prácticas para castigar la revelación de este acaban convirtiendo el secreto externo, que es la regla general, en ineficaz e inexigible en aquellos casos en los que existe un fuerte interés periodístico para conocer los detalles de la instrucción, muy cercano a veces al interés del público, lo que no debe confundirse con el

48 En esta línea y con especial contundencia se ha mostrado el Tribunal Supremo: «ciertamente, el bien jurídico protegido por la figura delictiva tipificada en el art. 417.1 CP es, con carácter general, el buen funcionamiento de las Administraciones Públicas y, en definitiva, el bien común como prioritario objetivo a que va dirigido el desempeño de la actividad de los funcionarios que las integran, en tanto que la revelación de los secretos e informaciones no divulgables irrogan un perjuicio de mayor o menor relevancia al servicio que la Administración presta a los ciudadanos. Nos encontramos, efectivamente, con un tipo penal abierto por imperativo de la realidad, toda vez que no resulta posible establecer casuísticamente en la norma los secretos e informaciones concretas cuya revelación integre la conducta típica». STS (Sala de lo Penal) núm. 1191/1999, de 13 de julio de 1999, FJ 3.

49 Precisamente, al deber de sigilo se han referido nuestros tribunales en los siguientes términos: «en tales hechos concurren las exigencias del tipo penal $[\ldots] 1^{\circ}$ ) El sujeto activo ha de ser un funcionario público o Autoridad, como en este caso sucede. $\left.2 .^{\circ}\right)$ La acción comisiva consiste en revelar, es decir, en hacer público lo que no debe serlo, sea de forma oral o mediante la entrega a terceros de escritos o papeles. $3^{\circ}$ ) Lo revelado tanto pueden ser secretos como «cualquier información»; concepto éste constituido por los hechos conocidos en atención al cargo u oficio que sin haber recibido la calificación formal de secretos son por su propia naturaleza reservados, protegiendo así la Ley el deber de sigilo de los funcionarios, impuesto en atención a la índole de los asuntos de que conocen, sean o no «secretos» en su sentido más estricto». STS (Sala de lo Penal) núm. 584/1998, de 14 de mayo de 1998, FJ 7.

50 Tal derecho no goza de una regulación legal específica, cosa que no ha impedido a la doctrina reconocer su aplicabilidad en el marco de los art. 20.1.d) y 24.2 de la Constitución. Fernández-Miranda Campoamor, A. (1990). El secreto profesional de los informadores. Temas claves de la Constitución española, Madrid, Tecnos, págs. 32 y ss. 
interés público informativo ${ }^{51}$. Existe en definitiva una evidente disparidad en la protección jurídica del secreto de sumario en nuestro país, así que no es de extrañar que la doctrina lo haya cualificado como un «defectuoso, ambiguo e impreciso sistema de garantía del secreto sumarial que favorece la formación de juicios paralelos, y consiguientemente, un cuestionamiento y descrédito de la actuación de los jueces ${ }^{52}$.

\section{b) En el juicio oral}

El principio de publicidad de las actuaciones judiciales en su dimensión externa cobra fuerza en la fase del juicio oral, en la que prevalece como regla general. Así se contempla en la mayoría de las leyes de enjuiciamiento continentales y en los textos internacionales ${ }^{53}$. En el ordenamiento jurídico español, la publicidad procesal como principio se encuentra recogida en el art. 120.1 de la Constitución, que establece que las actuaciones judiciales serán públicas, a excepción de lo que establezcan las leyes de procedimiento. Asimismo, el art. 24.2 de la Constitución recoge el derecho de toda persona a un proceso público sin dilaciones indebidas y con todas las garantías. La publicidad procesal actúa así, de un lado, como derecho y garantía de las partes procesales; del otro, como requisito para la formación de una opinión pública libre que controle la actuación de los jueces y magistrados en el caso concreto ${ }^{54}$, premisa que requiere también la publicidad del resultado del proceso, esto es, de las sentencias — art. 120.3 CE_, como analizaremos infra. Luego constituye un verdadero pilar del

51 Es el caso de la STC 54/2004, por ejemplo, en el que lo publicado son unas declaraciones de un preso contenidas en un sumario judicial, así como unas declaraciones de un tercero. La parte recurrida alegó que los contenidos del sumario habían sido obtenidos en vulneración del carácter secreto de este, pero el TC considera que tal extremo ni se probó en el juicio ni es contradictorio con el carácter fidedigno de la información, pues este último es independiente de la legitimidad en el modo de obtenerla y de las posibles responsabilidades a que pudiere haber lugar por ello. Véase la STC 54/2004, de 15 de abril, FJ 6. Paralelamente son muchos los casos que acaban en sobreseimiento porque es imposible acreditar quién revelo el secreto sumarial, principalmente, por la existencia del secreto profesional del periodista. Sirva como ejemplo el Auto Juzgado de Instrucción núm. 2 de Vitoria (Provincia de Álava), de 15 septiembre 2011, FJ 1.

52 Prat Westerlindh, C. (2013). Las relaciones entre el poder judicial y los medios de comunicación. Los juicios paralelos, Valencia, Tirant lo Blanch, 612.

53 El derecho a un juicio público se recoge en el art. 11 de la Declaración Universal de Derechos Humanos, en el art. 14.1 del Pacto Internacional de Derechos Civiles y Políticos, en el art. 6.1 del Convenio Europeo de Derechos Humanos, y, finalmente, en el art. 47.2 de la Carta de los Derechos Fundamentales de la Unión Europea. También la Convención Americana sobre Derechos Humanos de 1969 indica, en su art. 8.5, que «el proceso penal debe ser público, salvo en lo que sea necesario para preservar los intereses de la justicia».

54 En palabras del Tribunal Constitucional el principio de publicidad cumple la doble finalidad de «proteger a las partes de una Justicia sustraída al control público» y «mantener la confianza de la Comunidad en los tribunales». STC 96/1987, de 10 de junio, FJ 2. 
sistema democrático ${ }^{55}$, un derecho irrenunciable de la ciudadanía y un mecanismo para afianzar la confianza del pueblo en la actuación de los poderes públicos.

El derecho a un proceso público, por lo que a la dimensión sustantiva de la publicidad se refiere, constituye un auténtico derecho fundamental para las partes procesales — 24.2 CE_, lo que salvaguarda un juicio justo e imparcial. En cierto modo, la publicidad está conectada con todas las garantías del proceso penal ${ }^{56}$, y facilita la comprensión escénica del proceso en su conjunto y del cumplimiento de las garantías específicas que se derivan de la contradicción, la inmediación y la oralidad.

Por su parte, la dimensión adjetiva o formal de la publicidad tiene una clara vinculación con el principio democrático, ya que sólo así será posible el control por parte de la ciudadanía de las decisiones y actuaciones de uno de los poderes del Estado $^{57}$. Esta función de la publicidad está conectada inextricablemente con el derecho a la información —art. 20.1.a) y d)—y la institución de la opinión pública libre ${ }^{58}$.

La relación entre el Poder Judicial y los medios de comunicación no es, en definitiva, una opción. El público, la ciudadanía, tiene el derecho a saber y a ser informado sobre los procedimientos en materia penal, que están sometidos a la crítica colectiva, como las demás decisiones de quienes detentan el poder. Los reportajes y el seguimiento de los medios de comunicación social sobre la actividad judicial son un dispositivo básico de control social del Poder Judicial, cuya existencia se configura como condición necesaria para el correcto funcionamiento de la democracia.

La información judicial que facilitan los medios de comunicación, en términos generales, puede calificarse sin polémica como seria o solvente según los cánones de la buena praxis periodística, lo que contribuye sin lugar a duda a formar una opinión pública libre sobre asuntos de tanta transcendencia como es el funcionamiento de la administración de justicia. Tampoco el juzgador puede actuar aislado del entorno social y las decisiones que toma en los litigios de interés público responden a un diálogo continuo e inevitable con otros elementos sociales y políticos —académicos, prensa, el poder ejecutivo, el legislador, agencias administrativas y el público en general_ ${ }^{59}$. Un diálogo, en todo caso, necesario como recordaba en su día Francisco

55 De acuerdo con el TEDH «el carácter público de los procedimientos ante los Tribunales (...) contribuye a lograr la finalidad del artículo 6.1: el derecho a un juicio equitativo, cuya garantía constituye uno de los pilares fundamentales de una sociedad democrática en el sentido del Convenio». STEDH de 8 de diciembre de 1983, caso Axen contra Alemania, § 25.

56 En ese mismo orden de ideas se ha llegado a afirmar que la publicidad «equivale a todas las demás garantías procesales reunidas (...)». Aguilera de Paz, E. (1923). Comentarios a la Ley de enjuiciamiento criminal, Volumen V, Madrid, Ed. Reus, pág. 269.

57 En tal sentido el TEDH ha señalado que a los medios de comunicación «les compete comunicar informaciones e ideas sobre cuestiones de las que conocen los Tribunales, así como de aquellas que se refieren a otros sectores de interés público. A esta función de comunicación se añade el derecho del público de recibirla». STEDH de 27 de octubre de 1979, caso The Sunday Times, § 65.

58 Véase la STC 9/2007, de 15 de enero, FJ 4.

59 Véase sobre este particular la obra de referencia de Chayes, A. (1975). «The Role of the Judge in Public Law Litigation». Harvard Law Review, 89, 1281. 
Tomás y Valiente ${ }^{60}$. Por tanto, son ajustadas a Derecho las críticas que pueden molestar u ofender a un determinado órgano judicial o, incluso, a buena parte de la judicatura y ello, en principio, con independencia de la forma en la que se exterioricen ${ }^{61}$, lo que incluye obviamente el canal comunicativo.

Sin embargo, resulta fundamental separar y discernir esta actividad informativa que se encuentra claramente protegida por el ordenamiento jurídico, por cumplir con tan necesaria función en una sociedad democrática, de los programas específicos y especiales de infoentretenimiento de la prensa más amarillenta y de la llamada telebasura, que también tienen presencia y su reflejo en las redes sociales de Internet. Resulta realmente complejo, cuanto no imposible, atribuir esa prevalencia y protección reforzada también al infoentretenimiento judicial y a la patología de los juicios paralelos $^{62}$, siguiendo la definición que hemos propuesto para estos.

Sea como fuere, el carácter público de los procedimientos judiciales es uno de los mecanismos para preservar la confianza cívica en los juzgados y tribunales, y para ello, es necesario que alguien traslade al público lo que sucede en las salas de justicia ${ }^{63}$. O, dicho con otras palabras, la publicidad por sí sola no siempre reporta legitimidad para

60 «El Tribunal necesita la crítica de todos los juristas y, muy en especial, de los constitucionalistas. Leer, pensar y escribir es nuestra tarea cotidiana: la de los magistrados y letrados del Tribunal Constitucional y la de los constitucionalistas. Importa que nos leamos recíprocamente, e importa también que ustedes piensen y escriban sobre lo que nosotros decidimos. Decidir nunca es fácil, y, en más de una y de dos ocasiones, ayuda a hacerlo la lectura de una opinión, de una crítica de alguno de ustedes sobre algo ya resuelto por el Tribunal. Sepan, pues, que colaboran con nosotros. Sépanlo y continúen haciéndolo». Discurso del Presidente del Tribunal Constitucional en la apertura de las Jornadas sobre el Parlamento y sus transformaciones actuales organizada por la Asamblea Regional de Murcia en abril de 1988.

61 Rodríguez, A. (2016). El bonor de los inocentes y otros límites a la libertad de expresión relacionados con la Administración de Justicia, Valencia, Tirant lo Blanch, 418 y ss.

62 En relación con esto nos remitimos al interesante y exhaustivo estudio de Ángel Rodríguez en el capítulo quinto de su monografía, titulado «Actuaciones judiciales y ejercicio no preferente de la libertad de expresión». Rodríguez, A. (2016). El honor de los inocentes..., cit, 369 y ss. En particular, el autor considera que «no debería atribuirse una protección preferente a los actos que pudieran calificarse de «defensa mediática» que, por el contrario, deberían catalogarse como modalidades del ejercicio forense de la libertad de expresión, sujeta por ello a un régimen jurídico específico, en el que deberían incluirse también las relaciones con los medios de comunicación de todos los que están directamente implicados en los procesos judiciales. Tampoco deberían gozar de una posición preferencial los mensajes susceptibles de ser catalogados de «info-entretenimiento judicial», cuya protección por el ordenamiento debería partir de su escaso valor para la configuración de una opinión pública libre». Ibídem, 615.

63 Eliminar ese intermediario no es del todo fácil, incluso en los casos de televisación de los juicios o de visualización por streaming. Lógicamente la señal institucional o la URL del streaming pueden estar bajo el control de la administración de justicia, pero no es menos cierto que la gran mayoría de ciudadanos accederán a ese contenido a través de los medios de comunicación tradicional, que utilizan ese recurso y lo modelan en su propio espacio informativo. Así ha sucedido recientemente en casos mediáticos como el juicio por el procés, en el que se mezclaba la reproducción de partes de la vista vía señal institucional con espacios en los que tertulianos analizaban lo que se estaba sucediendo en la sala de justicia. Véase Quintero Olivares, G. (2019). «La Sentencia catalana..., cit., 113-114. 
el Poder Judicial ${ }^{64}$, y es que la primera debe ir acompañada del correcto funcionamiento del segundo y de un ejercicio periodístico preciso, completo y diligente ${ }^{65}$.

El derecho a comunicar o recibir libremente información sobre las actuaciones judiciales es compatible con la obligación de que esa información sea presentada de forma rigurosa ya que, en caso contrario, se corre el peligro de hacer aparecer como culpables ante la sociedad a personas que solo están o han sido investigadas. Los medios de comunicación social actúan, así, como un «termómetro de la legitimación del oficio judicial» ${ }^{66}$, y precisamente por ello, cuando se extralimitan en el ejercicio informativo, los efectos nocivos o perjudiciales se multiplican. Bajo ningún concepto puede defenderse la celebración de juicios paralelos en los medios, en base al principio de publicidad procesal o esgrimiendo el derecho a la información. Evidentemente, la dimensión formal o adjetiva de la publicidad procesal, que goza de una posición preferente en el sistema democrático, no es absoluta, y la crítica pública también debe estar sometida a límites, más aún cuando se canaliza a través de medios de comunicación social que realizan un ejercicio adulterado de las libertades informativas.

Procede en cualquier caso recordar aquí que lógicamente no se puede generalizar y en la mayoría de las ocasiones los medios de comunicación no llevan a cabo actuaciones de este estilo. Lo contrario implicaría demonizar a los medios de comunicación y concederles todo el protagonismo en la orquestación del juicio paralelo. De este modo, nos referimos en exclusiva a los juicios mediáticos que encajan con la definición que hemos propuesto de juicio paralelo, en los que se presentan opiniones como noticias y en el que participan todo tipo de personajes — defensores, detractores, testimonios, confesiones, víctimas, etc.—, muchas veces en calidad de expertos, y en los que se practican pruebas documentales y periciales con auténtico menosprecio sobre los derechos del investigado, que muchas veces puede quedar marcado o señalado de por vida. Este tipo de juicios, que proyectan a los estados de opinión pública una imagen distorsionada de lo que está sucediendo en el juicio penal, contribuyen a la desinfor-

64 Algunos autores enumeran eventuales consecuencias negativas de la publicidad, como su potencial contenido apologético. Sobre este extremo, el papel del informador al otorgar un determinado enfoque a la noticia es clave, y si esta se trata atendiendo tan sólo al objetivo comercial o al interés periodístico, se corre el riesgo de convertir el proceso en un espectáculo y al delincuente en un héroe. Véase Del Moral García, A. y Santos Vijande, J. M. (1996). Publicidad y secreto en el proceso penal, Granada, Comares, 47.

65 Lo expresa con claridad Gonzalo Sainz cuando proclama que «informar de los asuntos judiciales, como de cualesquiera otros, es, en el buen sentido de la palabra, manipular: sintetizar, resumir, encerrar en breves párrafos lo que las actas judiciales recogen en decenas, en centenares de folios muchas veces. La única garantía del correcto ejercicio del derecho de informar es la profesionalidad del informador». Gonzalo Sainz, M. A. (I999). «Justicia, información y opinión pública». Revista del Poder Judicial, especial XVII, 485-489.

66 Véase Gimeno Sendra, V. (1999). «La sumisión del juez a la crítica pública». Revista del Poder Judicial, especial XVII, 295-313. 
mación o infoxicación y no pueden estar amparados por las libertades informativas que paradójicamente vulneran en su vertiente pasiva ${ }^{67}$.

Con todo, los medios de comunicación son una parte importante de la ecuación, por lo que a la información judicial y difusión de esta se refiere. En este ámbito hace años que se planteó la fórmula de la autorregulación o el self-restraint, esto es, la aplicación de una serie de criterios e instrumentos relacionados con su actividad encaminados a garantizar que su actuación se ajusta a los valores y normas de dicha actividad, como podrían ser los códigos deontológicos ${ }^{68}$. La autorregulación no puede sustituir al Derecho, pero sí puede complementarlo, y devenir en un sistema más eficaz para asegurar la libertad informativa y las garantías judiciales ${ }^{69}$. Evidentemente, su funcionamiento y efectividad dependen esencialmente del compromiso que voluntariamente toman los propietarios de los medios de comunicación y los profesionales de la información. Hasta la fecha los códigos deontológicos, las buenas prácticas y los Consejos Audiovisuales no han conseguido evitar que se sigan produciendo juicios paralelos como el caso de La Manada. Quizás, la vía de la autorregulación en este ámbito está parcialmente condenada al fracaso, dada la gran cantidad de medios de comunicación existentes y la feroz competencia entre ellos, que hace que la supervivencia de una parte de estos dependa básicamente de la capacidad de atraer a la audiencia.

\section{c) Publicación y crítica de la resolución judicial.}

El ordenamiento jurídico español fue pionero al reinterpretar la publicidad íntegra de los textos de las resoluciones judiciales. En un primer momento, el vocablo interesado, al que se refieren los artículos 234, 235 y 266.1 de la LOPJ, fue interpretado por la jurisprudencia en un sentido amplio. Esa situación entrañó, en la práctica, el libre acceso por parte de la ciudadanía a los textos completos de las sentencias, tal y como de hecho estipulaba el Acuerdo del CGPJ ${ }^{70}$ del año 1989. Sin embargo, la doctrina del Tribunal Supremo cambió en el año 1995, de un lado, al empezar a distinguir, de manera taxativa, entre el derecho del público a estar presente en el

67 Véase Prat Westerlindh, C. (2013). Las relaciones entre el poder judicial..., cit, 218-240.

68 Véase sobre este particular Aznar, H. (2005). Comunicación responsable. La autorregulación de los medios. Barcelona, Ariel, págs. 14 y 15.

69 En esta misma dirección se muestra Carrillo cuando nos dice que «seguramente, la mejor solución es la que promueve la intervención del poder público en aquello que sea imprescindible y remite inmediatamente el resto a la autorregulación de las partes; de hecho, la complementariedad entre la regulación pública a través de la ley y la normación privada, mediante los códigos deontológicos y los estatutos de redacción, constituye en la actualidad de la información en España una fórmula de indudable interés para la tutela de los derechos del emisor y del receptor de la información». Carrillo, M. (1998). «El derecho a la información: entre la ley y la autorregulación», Parlamento y Constitución, 2, 119-131, pág. 124.

70 Véase el Acuerdo de 15 de noviembre de 1989 del Pleno del CGPJ. 
juicio y el derecho a obtener acceso al texto de la sentencia; del otro, delimitando el concepto de interesado como aquella persona física o jurídica que manifieste y acredite una conexión de carácter concreto y singular con el objeto del proceso ${ }^{71}$.

Esa nueva tendencia y línea jurisprudencial se ha asentado progresivamente en los acuerdos que ha ido aprobando sobre la materia el CGPJ y en diversos cambios legislativos. Asimismo, con la creación del CENDOJ en su día se dio un paso decisivo hacía la selección, ordenación, tratamiento, difusión y publicación de la información jurídica jurisprudencial, garantizando que el acceso y difusión de la información judicial se realice previo proceso de anonimización de los datos personales. En este particular, el ordenamiento español fue pionero en el contexto europeo, al aplicar y regular la técnica de la anonimización, por la que posteriormente optaron otros países como Alemania, Austria, Bélgica, Finlandia, Grecia, Hungría, Países Bajos, Polonia, Portugal y la República Checa ${ }^{72}$.

La publicidad de las sentencias es, entonces, relativa, ya que la divulgación al público no incluye aquello accesorio o irrelevante, como son los datos personales de los individuos que en ella aparecen ${ }^{73}$. De hecho, la protección y ocultación de los datos personales no impide la efectividad de los objetivos de la publicidad, ni pone en entredicho la seguridad jurídica que se deriva del conocimiento de la aplicación de las leyes.

Sin embargo, hay que señalar que la regulación actual de la difusión de la información judicial presenta situaciones paradójicas: las resoluciones de los órganos jurisdiccionales aparecen anonimizadas en la base de datos del CENDOJ empero las mismas aparecen publicadas íntegramente en los boletines oficiales o en los diarios digitales que han accedido a la sentencia y la han publicado en Internet. No deja de ser contradictorio, también, que cuando el caso llega al TC, la resolución de este último se publique íntegramente, dejando a cuerpo descubierto los datos personales que en las resoluciones de otras instancias han sido debidamente disociados.

Además, en los casos en los que existe interés público informativo, los medios de comunicación pueden tener acceso al texto íntegro de la sentencia como interesados. Parece evidente que ese acceso debería realizarse previa disociación de datos, puesto que los datos personales de la víctima y de los testigos u otros intervinientes - por poner un ejemplo - son totalmente accesorios y, por el contrario, su divulgación puede ocasionar daños irreparables al honor y buen nombre de las personas, así como a otros bienes jurídico-constitucionales. La realidad es que no se produce la anonimización y se entregan las resoluciones judiciales íntegras a los medios de comunicación. Se trata es una práctica extendida de facilitar el texto íntegro de la sentencia a los

71 STS (Sala de lo contencioso) núm. 1227/1995, de 3 de marzo de 1995, FJ 5.

72 Véase De Terwangne, C. (2005). «Diffusion de la jurisprudence via internet dans les pays de l'Union européenne et règles applicables aux données personnelles», Petites Affiches, 194, 9, disponible en: http://www.crid.be/pdf/public/5021.pdf (última consulta el 24 de junio de 2020).

73 Parte de la doctrina ha señalado este extremo como uno de los antecedentes del llamado derecho al olvido digital. Véase Simón Castellano, P. (2012). El régimen constitucional..., cit. 
medios, que a veces la cuelgan íntegramente en Internet ${ }^{74}$. Veremos, más adelante, como en el caso de La Manada también sucedió, haciendo pública la sentencia íntegra con los datos reales de la víctima, lo que el CGPJ achacó a un «fallo sistémico», aunque quizás habría que plantearse regular el acceso por parte de los medios ${ }^{75}$ y tratar de resolver las contradicciones de nuestro modelo actual.

\section{EFECTOS DE LA DESINFORMACIÓN SOBRE LOS DERECHOS INDIVIDUALES Y SOBRE EL PROCESO.}

El juicio paralelo constituye un ejercicio adulterado e inadecuado de las libertades informativas sobre hechos e informaciones relativas a procesos judiciales. A lo largo de las últimas tres décadas, como hemos visto, se ha mostrado un instrumento capaz de atentar de forma simultánea contra diversos derechos fundamentales recogidos en los artículos 18 y 24 de la CE — honor, presunción de inocencia, intimidad, propia imagen y otros bienes jurídicos dignos de protección como el derecho a un proceso justo e imparcial—, alcanzando a la propia imagen que del Poder Judicial tienen los ciudadanos.

Se evidencia así una clara patología informativa que plantea cuestiones de relevancia constitucional y cuya naturaleza encierra una complejidad extra, dado que la persecución de los excesos, de los menoscabos y de las intromisiones ilegitimas en los derechos, siempre se produce a posteriori.

Con todo, podemos clasificar la afectación de los juicios paralelos sobre los derechos fundamentales y sobre el proceso en dos grupos claramente diferenciados. Por un lado, el uso inadecuado de la información judicial puede cuestionar, como hemos analizado supra, el derecho a la presunción de inocencia del investigado como parte integrante del derecho a la tutela judicial y del derecho a un juicio justo, ampliando sus efectos a la imparcialidad y al principio de independencia judicial. Del otro, los conflictos también pueden producirse entre el derecho a comunicar información judicial y los derechos de la personalidad.

Respecto al primero de los grupos, parece incuestionable que la desinformación o posverdad sobre la actuación de los tribunales podría llegar a poner en cuestión el derecho a la presunción de inocencia del investigado como parte integrante del derecho a la tutela judicial efectiva. Que los medios afirmen la existencia de unos hechos antes de que así lo haga una sentencia judicial firme plantea problemas y puede crear

74 Por ejemplo, la publicación íntegra de la sentencia del Juzgado de lo Penal núm. 6 de Madrid, núm. 213/08, de 11 de junio de 2008, en la edición digital del diario El Mundo, disponible en: http:// estaticos.elmundo.es/documentos/2008/06/16/losantos.pdf (última consulta el 19 de febrero de 2011). En esta sentencia se condenó al famoso periodista Federico Jiménez Losantos, por un delito de injurias graves contra Alberto Ruiz-Gallardón, alcalde de Madrid en el momento de hacerse pública la sentencia.

75 Un acceso que, lógicamente, debe producirse, pero combinarse con la disociación de aquello que resulte accesorio como los datos personales e información sensible. 
una falsa apariencia de culpabilidad y una presión inadmisible sobre los jueces que tienen que decidir realmente sobre el asunto en cuestión ${ }^{76}$. Se trata, en cualquier caso, de jueces profesionales que deberían sortear tal presión y hasta que no surjan soluciones normativas específicas que ajusten la publicidad de la información sub iudice, «no cabe otra opción que analizar, en cada caso, si el juicio de autoría proclamado en la instancia ha tenido como fundamento el material probatorio generado en el plenario o, por el contrario, la percepción colectiva, anticipada e inducida por los medios de comunicación» ${ }^{77}$. Lo decisivo, siguiendo la doctrina del Tribunal Supremo, pasa por determinar si la percepción colectiva e inducida por los medios ha sido el fundamento de la decisión judicial ${ }^{78}$.

El derecho a la presunción de inocencia reconocido en el artículo 24.2 CE se proyecta sobre los procesos en los que es posible la adopción de resoluciones, tanto administrativas como jurisdiccionales, basadas en la condición o conducta de las personas. En un primer momento, la doctrina y la jurisprudencia entroncaron el contenido del artículo 24.2 de la CE, en exclusiva, a esa dimensión intraprocesal, es decir, se leía la presunción de inocencia como derecho de la persona frente a los poderes estatales, cuyos pronunciamientos condenatorios - ya sea en el proceso penal o en cualquier procedimiento administrativo sancionador- deben estar necesariamente fundados en pruebas que, legítimamente obtenidas, se hayan practicado con todas las garantías legalmente exigidas y a la postre desvirtúen tal presunción ${ }^{79}$.

Sin embargo, la doctrina jurisprudencial ha virado hacía una progresiva expansión del citado derecho hacía fuera del proceso, cuya aplicación también se predica hoy en día sobre relaciones intersubjetivas en el ámbito social ${ }^{80}$. O lo que es lo mismo, su proyección no se agota frente a los poderes estatales, sino que también es ejercitable frente a particulares ${ }^{81}$. Se trata de la dimensión extraprocesal que evita que se apliquen las consecuencias o los efectos jurídicos anudados a hechos de carácter delictivo o análogos en las relaciones jurídicas de todo tipo entre particulares.

Con todo, esta dimensión extraprocesal de la presunción de inocencia no es ejercitable frente a los particulares por la vía del artículo 24.2 de la Constitución, sino

76 En ese mismo sentido Quesada afirma que un juicio paralelo provoca «dos efectos indeseables: a) ejercer sobre los actores judiciales una presión que pueda llevarles a cambiar su percepción de las pruebas [...] y b) vulnerar el derecho de presunción de inocencia del que gozamos todos los ciudadanos hasta que no se pruebe nuestra culpabilidad». Quesada, M. (2012). «Juicios paralelos y medios de comunicación», en Mir Puig, S. y Corcoy Bidasolo, M., Protección penal de la libertad de expresión e información. Una interpretación constitucional, Valencia, Tirant lo Blanch, 292.

77 STS 587/2014, de 18 de julio, FJ 7.

78 Véase sobre esta misma cuestión la STS 4/2018, de 16 de enero.

79 Véase sobre este mismo particular la obra de Barrero Ortega, A. (2010). Juicios por la prensa y ordenamiento constitucional, Valencia, Tirant lo Blanch, 35-37.

80 Un estudio sobre la dimensión extraprocesal de la presunción de inocencia puede encontrarse en Cedeño Herán, M. (2000). «Algunas cuestiones suscitadas en torno al derecho a la presunción de inocencia a la luz de la jurisprudencia constitucional». Cuadernos de Derecho Público, 10, 203-214.

81 Véase la STC 166/1995, FJ 2. 
que se vehicula por la vía del artículo 18, como una cualidad intrínseca del derecho al honor ${ }^{82}$. La presunción de inocencia en su dimensión extraprocesal se revela, en definitiva, como una técnica de protección de la dignidad genérica de la persona frente a las imputaciones no probadas y, por supuesto, frente a desinformaciones, posverdades o programas que de forma sistemática ofrecen una información parcial o sesgada sobre el curso del proceso.

Esa tutela de la dimensión extraprocesal de la presunción de inocencia por la vía de los derechos de la personalidad es siempre reactiva, tras el menoscabo efectivo de la misma y del honor del afectado por la difusión de la desinformación judicial.

En consecuencia, la protección se procura a través del segundo grupo de derechos afectados por los juicios paralelos, es decir, por los derechos de la personalidad, y más concretamente, por el derecho al honor, a la vida privada y familiar. Todos ellos derechos conectados con la dignidad humana y el libre desarrollo de la personalidad ${ }^{83}$. Conforme a lo dispuesto en el artículo 10.1 CE, la dignidad de la persona se concreta en un conjunto de derechos inviolables que le son inherentes y, entre ellos, el derecho al honor, que presenta una vertiente interna o subjetiva — la dignidad de la personay una vertiente externa u objetiva — la imagen que la comunidad tiene del individuo y que proyecta sobre él- El honor, en su vertiente externa, se equipara a la reputación, honra, buen nombre o fama de la persona.

Los juicios mediáticos o paralelos constituyen una agresión a este derecho en la medida que hacen disminuir la estima o reputación, ya sea de los investigados o de la víctima, en el contexto social en que se desenvuelve. Tradicionalmente los juicios paralelos acostumbran a menoscabar el honor de los investigados, aunque también existen modalidades de agresión a la honra de la víctima ${ }^{84}$. El problema se percibe con mayor intensidad cuando el juicio acaba con la absolución del investigado, en cuyo caso el problema es la punición anticipada de la opinión pública, la estigmatización social y la difamación publica que ha sufrido ${ }^{85}$. La pena dictada por los juicios televisivos o por las redes sociales tiene un valor simbólico ${ }^{86}$ notable en nuestra socie-

82 En ese mismo orden de idas el TEDH ha vinculado la protección de la presunción de inocencia frente a ofensivas mediáticas bajo la cobertura de las previsiones del artículo 8 del CEDH. Véase López Guerra, L. (2019). «Juicios paralelos, presunción de inocencia y jurisprudencia del Tribunal Europeo de Derechos Humanos». Teoría y Derecho, Revista de Pensamiento Jurídico, 24, 47-49.

83 Véanse las SSTC 231/1988 y 214/1991, por todas.

84 Véase Planchadell Gargallo, A. (2019). «Publicidad del proceso e intimidad de la víctima: una aproximación desde el estatuto de la víctima del delito». Teoría y Derecho, Revista de Pensamiento Jurídico, 24, 150-177.

85 La misma problemática se observa en la prisión preventiva seguida de absolución. Sobre este particular véase Simón Castellano, P. (2020). «Presunción de inocencia e indemnización por prisión provisional indebida: interrogantes tras la STC 85/2019». La Ley Penal, 143, marzo-abril, en prensa; Abadías Selma, A. (2020). «¿Uso o abuso de la prisión preventiva?: consideraciones en relación al caso Sandro Rosell». La Ley Penal, 145, julio-agosto, en prensa.

86 En esa misma dirección Ferrajoli, L. (2000). Derecho y razón..., cit., 731-732. 
dad, por los efectos que genera en la imagen que el público tiene del investigado, con lo que el daño ocasionado en la honorabilidad es irreparable, aunque indemnizable.

La defensa frente a las agresiones al honor se realiza tradicionalmente a través de tres vías. La primera, el derecho de rectificación es, en realidad, de difícil aplicación en los juicios mediáticos, especialmente en el caso de programas televisivos de gran índice de share, y prácticamente imposible de concretar o ejercer en el ámbito digital por la propia naturaleza de las redes sociales y la incapacidad de los gestores de la red para poder dar una visibilidad parecida al texto de la rectificación. La segunda, la vía penal, reservada a los casos más graves con los tipos de calumnias e injurias. Y la tercera, la más habitual, la vía civil, a través del ejercicio de la acción de indemnización de daños por responsabilidad extracontractual y de las acciones para exigir las medidas cautelares y reparadoras, sean éstas indemnizatorias o no, reguladas en la Ley Orgánica 1/1982.

\section{JUICIOS PARALELOS Y REDES SOCIALES: EL CASO DE LA MANADA.}

La problemática tradicional de los juicios paralelos se proyecta también en Internet, cuya arquitectura en red permite que cualquier ciudadano pueda participar de forma instantánea en el debate. La transformación del tiempo-espacio y la libertad de difusión descentralizada y descontrolada en las redes sociales contribuye a pervertir y descontextualizar la información, en general, gracias a las aplicaciones de la web semántica, las operaciones algorítmicas y la minería de datos, que permiten viralizar los contenidos y captar la atención de los cibernautas ${ }^{87}$.

Los juicios paralelos, así como cualquier otro proceso comunicativo, se amplifican en las redes sociales por su arquitectura en red y su algoritmo de negocio. Procede estudiar si fruto de esa expansión también se incrementan exponencialmente los efectos perversos que los juicios paralelos producen de forma habitual en el mundo analógico o material.

\section{EL TRATAMIENTO INFORMATIVO}

Un buen ejemplo de los efectos 2.0 de los juicios paralelos lo podemos encontrar en el mediático caso de La Manada. Bajo esa denominación se han agrupado los sucesos relacionados con una violación múltiple acaecidos en el marco de las Fiestas de

87 Pueden consultar, para un estudio más al detalle de la «economía de la atención» del cibernauta, el trabajo de Wu, T. (2016). «An Introduction to the Law \& Economics of Information». Columbia Public Law Research Paper 14, 399. 
San Fermín en Pamplona del año 2016. El supuesto reúne buena parte de los factores que satisfacen el interés periodístico así que el seguimiento por parte de los medios de comunicación social fue constante desde la instrucción, durante la fase de juicio oral e incluso con posterioridad a las sentencias, en el marco de la fuerte discusión sobre la decisión judicial animada por parte de representantes del poder legislativo y, también, del ejecutivo. De hecho, el seguimiento e influencia fue tal que saltó al campo de la política-criminal, y se produjeron manifestaciones en todo el país en apoyo a víctimas de delitos contra la libertad sexual ${ }^{88}$.

El caso de La Manada reviste interés también porque en la propia sentencia aparece una referencia expresa a la presión mediática y a los juicios paralelos, y a la posible o eventual afectación al derecho a la presunción de inocencia. El letrado de la defensa, en la fase de cuestiones previas, planteó la cuestión de una posible vulneración de los derechos fundamentales y la presunción de inocencia de su representado durante la instrucción del caso ${ }^{89}$. El letrado argumentaba que la presión ejercida a través de las redes sociales había contaminado a testigos y peritos, y que ello tendría una clara incidencia a la hora de valorar la prueba. A tal fin, aportó documentación relativa a las publicaciones de un medio de comunicación social y también el resultado de las búsquedas en Google, es decir, las analíticas o estadísticas que muestran el volumen de búsquedas relacionadas con el tema ${ }^{90}$.

La Audiencia Provincial de Navarra rechazó la incorporación a los autos de tal documentación, en una decisión tomada por mayoría, al considerar que la pretensión del letrado de la defensa rebasaba el ámbito propio de cuanto es susceptible de valoración en el trámite de las cuestiones previas ${ }^{91}$. En la fundamentación jurídica de la sentencia no aparecen más referencias al juicio paralelo, aunque sí en el voto particular discrepante del criterio mayoritario de la Sala. El magistrado discrepante se refiere al «innegable, por notorio y evidente, juicio paralelo» vivido en el caso de La Manada y respecto de sus efectos cita doctrina jurisprudencial del Tribunal Supremo con el fin de señalar que «el discurso judicial nunca puede ser vicario de la voluble y a veces evanescente opinión pública» ${ }^{92}$. Sin embargo, no hace ninguna valoración específica de los efectos o proyección del juicio mediático en las redes sociales; tampoco valora el volumen y la clase de búsquedas en Internet, muy indicativos del seguimiento y estado de opinión al respecto, y se limita a recordar que la justicia

88 Véase sobre este particular Faraldo Cabana, P. (dir.); Acale Sánchez, M. (dir.); Rodríguez López, S. (coord.); Fuentes-Loureiro, M. A. (coord.). (2018). La Manada. Un antes y un después en la regulación de los delitos sexuales en España, Valencia, Tirant lo Blanch.

89 Véase la SAP Navarra, Sección 2a , núm. 38/2018 de 20 de marzo de 2018, Fundamentos de derecho, apartado primero. Véanse también sobre el caso las STSJ Navarra, Sala de lo Civil y Penal, núm. 8/2018 de 30 de noviembre de 2018; STS 344/2019, de 4 de julio de 2019.

90 Ibídem, apartado primero letra $\mathrm{H}$ ).

91 La doctrina ya ha tenido ocasión de valorar positivamente este extremo. Véase Carrillo, M. (2019). «Derechos fundamentales y Poder Judicial en la Sentencia de la Manada». Teoría y Derecho, Revista de Pensamiento Jurídico, 24, 81-82.

92 STS 854/2010, de 29 de septiembre. 
paralela no es justicia y que el juez no puede comprometer su imparcialidad objetiva, sin extraer conclusión concreta de los efectos sobre la imparcialidad de los juzgadores.

\section{a) Medios analógicos y programas televisivos}

Durante la instrucción del juicio de La Manada fueron muchas las cadenas de televisión que realizaron especiales o programas que hacían un seguimiento casi a diario de los «avances» en el caso. Cabe distinguir aquí el tratamiento realizado por parte de los medios de comunicación, que en general se limitaron a divulgar las noticias en base a su criterio editorial, del realizado por parte de programas televisivos de la llamada telebasura. Un estudio interesante y minucioso basado en el seguimiento realizado por parte de los programas «Equipo de Investigación» de La Sexta, «Especiales Noticias» de Antena 3 y «El programa de Ana Rosa» de Telecinco llega a la conclusión que los tres reiteraron demasiado — contenido repetitivo, imágenes recurso o vídeos sobre acusados, detalles innecesarios para entender los hechos pero atractivos para el público - la cobertura del caso priorizando otros intereses, los cuales conducen al infoentretenimiento o al sensacionalismo, antes que elaborar informaciones respetuosas y éticas tal y como se propone en códigos deontológicos de la profesión ${ }^{93}$. Sin embargo, el mismo estudio advierte que el tratamiento fue mucho más respetuoso por parte de «Especiales Noticias», y en menor grado por parte de «Equipo de Investigación», que utilizaron un formato más informativo que «El Programa de Ana Rosa», que por el contrario abusó de recursos repetitivos y mostró una tendencia orientada al entretenimiento del público, con titulares como «La foto de La Manada al completo», «La carta de la víctima» o «Ana Rosa se suma al Yo Sí Te Creo».

El tratamiento televisivo por parte de los programas orientados al entretenimiento fue, en general, bastante lamentable. Para muestra un botón. En una tertulia del programa La sexta noche emitido el sábado 31 de abril de 2018 los «expertos» o tertulianos afirmaron que «los condenados por el delito a tan solo 9 años de prisión estarán en la calle en pocos meses», que «no he visto el juicio, pero la prueba está mal valorada» y que «yo no sé Derecho, pero la interpretación de la norma es equivocada».

Por su parte, las once sesiones de la fase del juicio oral tuvieron un seguimiento informativo más que notable. Como señalábamos anteriormente, además de la cobertura en muchos noticiarios, en los que el tratamiento en cuestión se enmarcaba por

93 Se trata de un estudio cuantitativo y cualitativo del seguimiento informativo del caso La Manada. Véase Aurrekoetxea Jover, I. (2019). «El caso de La Manada a través de la contextualización en la televisión. Análisis y comparación del tratamiento periodístico en Equipo de Investigación, Especiales Noticias Antena 3 y El programa de Ana Rosa», Trabajo Final de Grado tutorizado por María Josep Picó Garcés, Universitat Jaume I, disponible en: http://hdl.handle.net/10234/186075 (última consulta el 24 de junio de 2020). 
lo general dentro de las libertades informativas, el caso fue el tema estrella durante meses en programas como «La Mañana de la 1 » $\mathrm{o}$ «El programa de Ana Rosa», entre muchos otros espacios televisivos que tienen un formato más orientado al entretenimiento. Tal y como es habitual en esta clase de programas, no se informaba estrictamente sobre el juicio, sino que más bien se aportaban datos de la vida y entorno de los acusados, informaciones e imágenes de la víctima y comentarios u opiniones de «expertos», sin tener nunca el apoyo de juristas de reconocida solvencia ${ }^{94}$.

La responsabilidad, en este ámbito, no puede atribuirse en exclusiva a los programas de la llamada telebasura. Cabe recordar que la defensa de dos de los acusados participó en las tertulias televisivas durante la instrucción, realizando también declaraciones a la puerta de la Audiencia y entrevistas en los platós de los programas televisivos más amarillistas. El papel de ciertos operadores jurídicos, en este caso, el desempeñado por determinados abogados de la defensa, coadyuvo al juicio mediático al exponer tesis muy provocativas fuera de las salas de justicia, relacionadas con el comportamiento de la víctima, previo y posterior a los hechos enjuiciados, tratando de sembrar en la opinión pública un clima hostil que pusiera en duda la honestidad de esta y, por ende, aumentase la presión sobre la valoración judicial de su testimonio.

Tampoco ayudaron determinadas filtraciones durante la instrucción, muchas de ellas entendemos propiciadas por la información facilitada por las propias partes procesales, o incluso que se facilitase a los medios la sentencia íntegra, previa disociación o anonimización, lo que el CGPJ cualificó como un fallo «sistémico» que propició que los nombres y apellidos de la víctima, así como otros datos de esta, se hiciesen públicos ${ }^{95}$.

El juicio mediático se extendió también al escenario post sentencia. De hecho, el episodio vivido tras la primera de las sentencias del caso «La Manada» es uno de los más nefastos en la historia de nuestra democracia por lo que a separación de poderes se refiere. La reacción a la SAP Navarra, Sección 2a , núm. 38/2018 de 20 de marzo de 2018 fue encabezada por críticas y descalificaciones por parte de representantes tanto del poder legislativo como del ejecutivo, al más alto nivel institucional ${ }^{96}$. Las asociaciones de jueces y magistrados calificaron la respuesta como desproporcionada y el presidente del Tribunal Supremo y del Consejo General del Poder Judicial, Carlos

94 Véase Gálvez González, A. (2019). «Juicios paralelos y presunción de inocencia. Análisis comparado del tratamiento informativo del caso de La Manada en La Mañana de la 1 y El Programa de Ana Rosa», Trabajo Final de Grado tutorizado por Marta María Redondo García, disponible en: http:// uvadoc.uva.es/handle/10324/39695 (última consulta el 24 de junio de 2020).

95 Véase la noticia «El Poder Judicial concluye que el nombre de la víctima de la Manada se filtró por «un fallo sistémico»», en el diario ABC, disponible en: https:/cutt.ly/yifHCPj (última consulta el 25 de junio de 2020).

96 Sirvan como ejemplo las declaraciones del por aquél entonces Ministro de Justicia que llego a afirmar que «todos saben que el juez que emitió el voto particular en la sentencia de La Manada tiene un problema; el CGPJ debería haber actuado». Véase la noticia en el diario El Mundo, disponible en: https://cutt.ly/zifWMM9 (última consulta el 25 de junio de 2020). 
Lesmes, tuvo que salir en defensa de la Audiencia Provincial y de los tres magistrados que la dictaron ${ }^{97}$.

\section{b) Medios digitales $y$ redes sociales}

Nada nuevo bajo el sol hasta aquí: los tradicionales juicios paralelos en prensa escrita, radio y muy especialmente en televisión, con programas especiales y la cobertura de los llamados programas telebasura. Con todo, en el caso de La Manada el seguimiento online fue masivo ${ }^{98}$. En la red social Twitter se popularizaron hashtags o etiquetas como \#LaManada, \#BoicotAlAbogadoDeLaManada, \#EstaEsNuestraManada, \#YoSiTeCreo, \#LaManadaALaCarcel. Se trata sólo de una pequeña muestra de etiquetas que invitan a participar en el debate a los cibernautas sobre el tema en cuestión, y que como se observa, emplean terminología bélica. En ocasiones el propio contenido literal de la etiqueta entraña una ilicitud manifiesta o fines espurios, como en el caso de la etiqueta que propone boicotear al abogado de la defensa. En otras, se apela a los cibernautas a dejarse llevar por sus impulsos y pasiones, lo que se traduce en expresiones sensacionalistas, inveraces o agresivas. Por su parte, el lema «yo sí te creo», pretende claramente ejercer presión sobre los jueces y magistrados e influenciar la decisión de estos.

Es en este ámbito en el que interesa recordar que, de entrada, Internet y las redes sociales suponen un nuevo abanico de posibilidades para el ejercicio de las libertades informativas. Sin embargo, esa feliz apariencia de libertad encierra probablemente la artimaña más seductora de la red. Me refiero a la falacia de las redes sociales, en las que es muy fácil añadir amigos o borrarlos, sin que el cibernauta disponga de habilidades sociales tan básicas como mantener un diálogo y ser capaz de aceptar la crítica de un tercero. En las redes sociales es difícil que algo así suceda, ya que los algoritmos que regulan su funcionamiento no pretenden involucrar a sus usuarios en un diálogo real. Desde una óptica comercial, para qué enfrentar a los usuarios a dificultades o hacerles llegar mensajes que desmontan o contrastan los suyos.

Como consecuencia, es difícil, cuando no imposible, encontrar auténticos espacios públicos racionales de debate en Internet. Existen foros, por supuesto, pero muy

97 Véase el Comunicado del presidente del Tribunal Supremo y del Consejo General del Poder Judicial de 27 de abril de 2018, difundido a través del canal «El CGPJ informa». Además, frente a la cascada de reacciones contrarias a la sentencia de la Audiencia Provincial en el caso de La Manada, 750 jueces españoles presentaron una queja ante el Consejo Consultivo de Jueces Europeos denunciando una gravísima amenaza para la independencia judicial en España y pidiendo amparo internacional por la presión social que se produjo en el citado asunto. Véase Presno Linera, M. A. (2018). «Proceso penal..., cit, 57.

98 Ha sucedido también en otros casos tan significativos como los de Diana Quer, Ana Julia Quezada, el caso Arandina, Asunta Basterra, etc., aunque probablemente el caso de La Manada es el más paradigmático de todos hasta la fecha por lo que se refiere a seguimiento en medios digitales y redes sociales. 
alejados del modelo teórico de limitación y garantía de los poderes, sometidos o sujetos a la crítica pública. El ciudadano acostumbra más a utilizar esos foros para expresar su enojo de formas muy diversas que nada tienen que ver con la idea ilustrada de una opinión pública libre que controle el ejercicio de los poderes ${ }^{99}$. Se trata de un efecto que Ramírez Ortiz califica como el «derrumbe del modelo de crítica pública» y la «liquidación del modelo penal y procesal constitucional» ${ }^{100}$.

Sea como fuere, las redes sociales no enseñan a dialogar porque es más rentable conectar usuarios que piensan lo mismo ${ }^{101}$. En lugar de ampliar horizontes, se limitan, y el efecto es que el usuario tiende a pensar que sus ideas y convicciones son apoyadas por una mayoría indiscutible de personas. Téngase en cuenta que cuando uno accede a esa clase de redes, el algoritmo tiene en cuenta la huella digital del dispositivo desde el que se conecta ${ }^{102}$, y eso implica tener acceso y procesar datos tan relevantes como el histórico de geolocalización, la agenda de contactos, los correos electrónicos vinculados, el acceso a la cámara y a las fotos, el historial de los navegadores utilizados, etc. De ese modo, ya de entrada, la red social te aconseja solicitar amistad de aquellos que no sólo puede ser que conozcas, sino que probablemente tienen puntos de vista cercanos al tuyo en lo político.

La selección de la información en las redes sociales tiene un efecto realmente negativo porque distorsiona la forma como el usuario accede a la información, a través

99 Para algunos autores ese derrumbe se produjo con anterioridad a la revolución digital. Touraine vincula su destrucción al auge de los medios de comunicación de masas y al éxito de los programas de televisión cuando nos dice: «los medios de comunicación de masa y especialmente la televisión han dado una expresión pública a los problemas privados. Yo creo que esta enorme transformación del campo político está directamente vinculada a los medios de comunicación. Los grandes debates en la televisión mundial no tienen mucho que ver con nacionalización o privatización de industrias (...) Los debates en la televisión son más importantes que los debates en el parlamento. (...) Los medios de comunicación de masa se dedican al proceso público de los problemas privados, y por eso lo que nos impresiona más en la televisión es siempre la visión de un individuo, de un destino. Es la novela moderna». Touraine, A. (1996). Los mass media: ¿Nuevo foro político o destrucción de la opinión pública?, conferencia pronunciada con motivo de la entrega del VII premio a la investigación sobre comunicación de masas, Barcelona, Centro de Investigación de la Comunicación, 23.

100 Ramírez Ortiz, J. L. (2019). «La justicia penal en la sociedad digital». Teoría y Derecho, Revista de Pensamiento Jurídico, 24, 51-63.

101 Sunstein ha formulado una crítica al funcionamiento de las redes sociales que ha sido muy aplaudida por la doctrina. El autor advierte sobre las posibilidades que Internet tiene de convertir a los individuos en meros consumidores egoístas, que sólo escuchan el eco de sus propias voces y se aíslan de las demás. Y matiza la noción de libertad a la que se refieren habitualmente algunos proveedores de servicios de Internet, recordando que ésta «no sólo consiste en satisfacer las preferencias, sino también en la oportunidad de tener preferencias formadas en condiciones decentes; en la capacidad de tener preferencias formadas tras haber estado expuestos a una cantidad suficiente de información y también a una cantidad, adecuadamente amplia y variada de opciones». Sunstein, C. R. (2003). República.com, Internet, democracia y libertad, Barcelona, Paidós, 56.

102 Véase el «Estudio Fingerprinting o Huella digital del dispositivo» de la Agencia Española de protección de datos: https://www.aepd.es/sites/default/files/2019-09/estudio-fingerprinting-huelladigital.pdf (última consulta el 1 de abril de 2020). 
del timeline o muro, sin ser consciente que lo que lee ha sido ordenado y estructurado con preferencias de mercado. Con ello se encierra a los usuarios en lo que Zygmunt Bauman ha llamado zonas de confort, donde «el único sonido que oyen es el eco de su voz, donde lo único que ven son los reflejos de su propia cara» ${ }^{103}$.

Lo anterior convierte las redes sociales en el caldo de cultivo idóneo para las noticias falsas o fake news, la desinformación y la llamada posverdad ${ }^{104}$. No se trata de un fenómeno nuevo, aunque algunos de estos conceptos se hayan acuñado o popularizado recientemente. En realidad, desde el nacimiento de la esfera pública han sido muchos los intentos de pervertirla. Los medios de comunicación han sido tradicionalmente considerados el instrumento más eficaz de influencia a la opinión pública, al desarrollar un papel que les permite tener efectos políticos inmediatos, pero también consecuencias a largo plazo o efectos mucho más duraderos y profundos. De hecho, son los medios de comunicación social los que construyen las representaciones comunes de la realidad social. Todo ello se ve, simplemente, magnificado en el contexto digital, en el que se produce la inquietante paradoja de que los usuarios que tienen acceso a la más completa base de datos e información son, paralelamente, más ignorantes y superficiales que nunca ${ }^{105}$.

En ese mismo orden de ideas, no puede despreciarse el rol que juegan los medios de comunicación social, también cuando estos plantean problemas o debates en las redes sociales de forma proactiva, como en el caso de La Manada ${ }^{106}$. Los periodistas se

103 Véase la entrevista a Zygmunt Bauman publicada en el diario El País el 9 de enero de 2016, disponible en línea: https://elpais.com/cultura/2015/12/30/babelia/1451504427_675885.html (última consulta el 1 de abril de 2020); también su obra Bauman, Z. (2010). Vida líquida, Barcelona, Paidós. Sobre este mismo fenómeno puede leerse la interesante obra de Spitzer, M. (2013). Demenciadigit@l, Barcelona, Ediciones B.

104 Los bots contribuyen decisivamente a ello, como se estudia en Shao, C. et al. (2018). «The spread of low-credibility content by social bots». Nature Communications, 9: 4787. Disponible en: https:// www.nature.com/articles/s41467-018-06930-7 (última consulta el 1 de abril de 2020).

105 Algunos autores como Baricco sostienen que Internet afecta negativamente a las libertades en la medida que la información divulgada o encontrada haya sido previamente objeto de manipulación, sea nociva o refuerce la dinámica bárbara de la sociedad. Más concretamente, el citado autor habla de «dinámica bárbara» para hacer referencia al declive de la cultura burguesa occidental enlazado al avance tecnológico y, en especial, a Internet, que incluye nuevas posibilidades de hacer surfing y navegar en la experiencia de la realidad, esto es, permite moverse por la superficie del saber y de la vida cambiando de un tema a otro sin ninguna necesidad ni voluntad de profundizar en el fondo. Baricco, A. (2009). Los bárbaros: ensayo sobre la mutación, Barcelona, Anagrama.

106 Una de las principales conclusiones que se alcanza en un estudio sobre el tratamiento mediático por parte de los medios digitales Diario.es, ABC.es y Elpais.com en el caso de La Manada es que los medios consiguieron movilizar las personas a través de las redes sociales, ofreciendo una instantánea, liderando el mensaje y garantizando la actualización e interacción constante con el público. Además, se observa que dos de los medios analizados utilizaron la actualización en directo para informar de la lectura de la sentencia; en una sola página iban añadiendo las nuevas informaciones y reacciones que llegaban en tiempo real, en vez de crear diferentes noticias separadas, apostaron por integrar toda la información en una sola, de forma que el lector pudiera seguir de manera cronológica todo lo que estaba ocurriendo. Véase Liarte Marín, C. y Bandrés Goldáraz, E. (2019). «La objetividad y neutralidad de la información 
sirven de las redes sociales para transmitir información a tiempo real y conectar con más usuarios que puedan tener opiniones parecidas o cercanas a su línea editorial ${ }^{107}$. El fenómeno viral tiene habitualmente como punto de partida un medio de comunicación, salvo algunas excepciones en las que ese efecto se ha conseguido directamente por parte de un usuario o cibernauta ${ }^{108}$. Los medios de comunicación social están muy presentes en Internet y crean corrientes de información para alimentar a diario sus propias redes sociales, como en el caso de La Manada ${ }^{109}$, lo que les permite de un lado satisfacer su interés periodístico — comercial, publicidad e ingresos vía generar tráfico de entrada a su página web principal y a los demás micromedios que están en su órbita de retroalimentación — y, del otro, su interés público — contenidos e hilos que refuerzan los posicionamientos políticos e ideológicos-

Todo ello resulta perfectamente aplicable a la información sobre procesos judiciales. Los medios utilizan las redes sociales para satisfacer su doble interés, periodístico y público, y cuando informan sobre esta clase de procesos, o incluso sobre cuestiones de política criminal ${ }^{110}$, les interesa que el tema se convierta viral, hasta que se

en la red: el tratamiento del Diario.es, ABC.es y El País.com en el juicio contra «la manada»». Journal of Communication, 18, 119-140.

107 En el estudio citado en la nota anterior también se concluye que, en relación con el grado de objetividad, los medios ABC.es y Elpaís.com no logran ser objetivos, mientras que Eldiario.es roza casi la plena objetividad. Además, el tratamiento de los tres medios se produjo de formas muy distintas que coinciden con la línea editorial de cada uno de estos: uno en la dirección de humanizar a los investigados, el otro al criticar a los jueces por «no creer» a la víctima y, finalmente, el último, informando de forma más neutral. Ibídem.

108 Sobre el papel de los medios de comunicación en las redes sociales y su participación decisiva para viralizar los contenidos online, véase García Sanz, R.M. (2017). Digital Journalism. Rethinking Communication Law to Support Democracy and Viable Business Models, Palo Alto, Academica Press.

109 Un interesante estudio del tratamiento informativo en el caso de La Manada ha puesto de manifiesto la trascendencia de las redes sociales para difundir contenidos de la edición digital, sobre todo, en aquellos casos en los que dicho formato es el principal. Más concretamente del citado estudio se extraen datos como por ejemplo que el $100 \%$ de las publicaciones de Okdiario sobre el caso de La Manada en redes como Facebook incluían enlace hacia la edición digital, al igual que ocurre con Eldiario. es. A nivel general, los medios que más publicaciones dedicaron al desarrollo del juicio o a sus protagonistas en Twitter o Facebook fueron ABC y Eldiario.es, con 49 y 46 publicaciones, respectivamente, mientras que el que menos atención dedicó fue Okdiario, con 19 publicaciones. Véase Villalobos Aguilera, G. F. y Monedero Morales, C. R. (2019). «Redes sociales y contenidos sensibles: tratamiento del juicio a La Manada en perfiles de diarios generalistas españoles», en Fernández Blanco, E. (ed.)., La gestión de los contenidos en comunicación, Madrid, ESIC - EDITORIAL, 231-236.

110 Un ejemplo paradigmático de la influencia de los medios a través de las redes sociales sobre los procesos de política criminal lo encontramos en el caso de las campañas mediáticas sobre la violencia de género en España entre 2000 y 2012. Véase sobre este particular Varona Gómez, D. y Gabarrón, N. (2015). «El tratamiento mediático de la violencia de género en España (2000-2012): agenda setting y agenda building». InDret, 2/2015, 38-41. Entiéndase que la efectividad de estas estrategias por parte de los medios depende de la capacidad del grupo de presión para trasladar esa presión, valga la redundancia, a los partidos políticos y a las instituciones. En una sociedad como la nuestra, en la que estamos llamados a la batalla por el titular en la red, es más fácil incidir sobre los segundos a través de las redes sociales de Internet. O dicho con otras palabras, la política depende cada vez más de la imagen 
agote el tema o la audiencia, por eso a nadie debería sorprender el tratamiento informativo en el caso de La Manada ${ }^{111}$. Esta acción no es exclusiva de Internet, sino que se realiza muchas veces en paralelo con los ya criticados programas telebasura o especiales de televisión. El caso de La Manada es un buen ejemplo de como los medios de comunicación alimentaron los juicios paralelos a través de Internet y las redes sociales, abriendo el debate sobre ciertos procesos penales en espacios de debate desestructurados, fragmentarios y superficiales, combinando el formato de programa telebasura, en el que participan los tradicionales «tertulianos» o «expertos», con el estilo abierto de Internet, que permite que cualquiera opine desde el anonimato.

El escenario resultante no es nada halagüeño para los derechos de las partes procesales implicadas. La dinámica y estructura de las redes refuerza las líneas argumentales y contribuye a magnificar, más que el debate, la discusión y el exceso. El algoritmo hace que a los detractores de los investigados les aparezcan mensajes críticos o acusadores, como los suyos. Y lo mismo en relación con los defensores. Las posiciones se refuerzan no a nivel cualitativo, sino cuantitativo, y el resultado es que la discusión se sitúa en los límites del ejercicio de las libertades informativas cuando no los excede. Que una intromisión ilegítima en el honor pueda ser retuiteada por miles de usuarios eleva los efectos lesivos que son, además, consecuencia de todos los que han realizado esa acción, no sólo del que ha emitido el mensaje en origen ${ }^{112}$.

Con todo, a pesar de que la mecha que prende el juicio paralelo en las redes sociales a veces pueda tener su origen en el interés periodístico de los medios de comunicación social, no es menos cierto que el control sobre el mismo se pierde en el momento en que la información se convierte en viral. De hecho, la pérdida de mediación social por parte de los profesionales de la información, de los medios de comunicación y de las fuentes informadas o expertas constituye la raíz o base del clima dominante de posverdad y desinformación en las redes sociales ${ }^{113}$. En ese instante son los cibernautas los que contribuyen a mantener y ensalzar el juicio paralelo, al expresar opiniones muy alejadas del ideal de crítica pública ilustrada, que normalmente muestran

transmitida por los medios y del estado de opinión de las redes sociales online. Sobre la presión sobre los gobernantes y la perdida de influencia de la institución de la opinión pública informada véase Varona Gómez, D. (2011). «Medios de comunicación y punitivismo». InDret, 1/2011, 1-34.

111 Véase Villalobos Aguilera, G. F. y Monedero Morales, C. R. (2019). «Redes sociales..., cit, 231-236.

112 Véase la STS 706/2017, de 27 de octubre. Se recomienda también la lectura de Cabellos Espiérrez, M. A. (2018). «¿Retuitear es delito? A propósito de la STS 706/2017, de 27 de octubre». Revista Catalana de Dret Públic, online, https:/eapc-rcdp.blog.gencat.cat/2017/12/13/retuitear-es-delitoa-proposito-de-la-sts-706-2017-de-27-de-octubre-miguel-angel-cabellos-espierrez/ (última consulta el 1 de abril de 2020).

113 Se trata precisamente de la principal conclusión a la que llega Blanco Alfonso en un estudio, de corte teórico, que propone una aproximación desde la fenomenología al debate sobre la posverdad en Internet. El autor señala que la inexistencia de fuentes informadas o medios de comunicación social con capacidad para mediar en los entornos en línea constituye el origen y la base del clima dominante de posverdad y desinformación en la red. Blanco Alfonso, I. (2020). «Posverdad, percepción de la realidad y opinión pública. Una aproximación desde la fenomenología». Revista de Estudios Políticos, 187, 167-186. 
enojo, crítica fácil o argumentos populistas ${ }^{114}$. De todo ello se benefician los medios y los demás actores interesados, que posicionan y aceleran la retroalimentación y el tráfico web, de la que proceden la gran mayoría de ingresos publicitarios en Internet. La penetración de los tradicionales medios en las redes sociales de Internet no sólo se produce por ese interés periodístico y económico ${ }^{115}$, sino que también, como hemos dicho en relación con el mundo analógico, por su interés público de conformar grupos de presión y trasladar a la opinión pública informaciones que puedan marcar el devenir de la justicia penal.

Se evidencia de ese modo que las redes sociales son productoras de noticias y contenidos basura cuya conexión con las ediciones digitales de los medios de comunicación social tradicionales — periódicos, radio y televisión- es multidireccional; se retroalimentan unas y otras. La lucha por el trending topic por parte de los medios y de los cibernautas es, en realidad, la lucha por la audiencia en un entorno, el digital, que obedece a un algoritmo egoísta y simplista, que reduce o empequeñece los debates y parece condenarte al eco de tus propias ideas.

\section{EFECTOS DE LA DESINFORMACIÓN EN INTERNET SOBRE LOS DERECHOS INDIVIDUALES.}

En el caso de La Manada, el Tribunal rechazó la documentación aportada de parte con el fin de acreditar la existencia de un juicio mediático en Internet; una decisión que parece acomodarse en sólidos argumentos. El juicio paralelo, como se ha visto, no debe ni puede afectar a la dimensión intraprocesal de la presunción de inocencia y tampoco a la imparcialidad de los magistrados; los efectos sobre la dimensión extraprocesal se ventilarán a través de la tutela de la dignidad humana y los derechos de la personalidad, en procesos ajenos y posteriores al proceso penal. Nadie duda de la existencia del juicio paralelo, que es evidente, pero ello no implica que se limite la imparcialidad de los juzgadores ni la dimensión intraprocesal de la presunción de inocencia.

En este sentido cabe recordar que el modelo que inspira nuestro ordenamiento jurídico goza, de entrada, de una protección mayor de la imparcialidad judicial. Los jueces profesionales tienen un mayor blindaje ante la influencia de los medios de comunicación social, ya sea la prensa escrita, la radio, la televisión o las redes sociales e Internet. La razón es simple, se trata de jueces profesionales ${ }^{116}$ que han accedido a

114 Véase Ramírez Ortiz, J. L. (2019). «La justicia penal..., cit., 51-63.

115 La línea editorial también despliega sus efectos tal y como señalan Liarte Marín, C. y Bandrés Goldáraz, E. (2019). «La objetividad y neutralidad... cit.

116 En esta misma línea argumental Presno Linera señala que «tampoco tenemos la impresión de que lo acontecido las horas y días siguientes a conocerse la sentencia del caso «la manada», en forma de concentraciones y manifestaciones en diferentes ciudades y de efervescencia en las redes sociales, haya supuesto o suponga en un futuro próximo una amenaza creíble a la independencia judicial, ni en general 
la carrera judicial tras superar una oposición basada en los principios de mérito y capacidad, que han sido formados e instruidos por la Escuela Judicial y que están capacitados para, en definitiva, no sucumbir ante la presión de la opinión pública. Esa formación y capacitación limita y reduce de forma considerable las posibilidades de que los juicios paralelos afecten a la imparcialidad del juzgador y a la presunción de inocencia en su vertiente intraprocesal.

Por lo que se refiere al caso de la Manada, el TS tuvo la oportunidad de verificar si los tribunales a quo se vieron sobrepasados por la presión mediática y, más concretamente, si las noticias del caso, las concentraciones de repulsa social y las manifestaciones del Ministro de Justicia en el marco del juicio paralelo, habían podido llegar a lesionar objetivamente la imparcialidad del juzgador. Lo rechaza de pleno el Alto Tribunal al considerar que las resoluciones judiciales acaecidas en el caso de La Manada se cimientan en sólidos argumentos, con una motivación exhaustiva y en el marco de una causa que se desarrolló tras un proceso con todas las garantías ${ }^{117}$. Buena muestra de la libertad de criterios y de valoración probatoria de los magistrados es, precisamente, la discrepancia entre estos, tanto en el juicio celebrado ante la Audiencia Provincial, cuya sentencia cuenta con un voto particular, como en la sentencia de apelación del Tribunal Superior de Justicia, en la que constan dos votos particulares. Además, que el fallo finalmente coincida con un cierto estado previo de opinión resulta intrascendente cuando tal conclusión aparece como resultado natural, lógico y coherente de los elementos de convicción ofrecidos por las distintas fuentes de prueba practicadas en el acto de juicio.

En consecuencia, los efectos del juicio paralelo en las redes sociales e Internet, por lo que se refiere a la imparcialidad judicial y al derecho a la presunción de inocencia intraprocesal, no presentan diferencias sobre los juicios paralelos en el mundo analógico, puesto que en ambos casos la afectación debería resultar, en la práctica, inexistente, siguiendo la interpretación y criterio del TS en el caso de La Manada ${ }^{118}$.

Este corolario, en cambio, es inalcanzable en los juicios por jurados, más habituales en los sistemas jurídicos del common law. En ese supuesto, los efectos nocivos de las redes sociales han podido socavar los cimientos del derecho a un juicio justo,

ni tampoco para este caso concreto: por una parte, el tribunal que emitió el fallo ya cumplió con su cometido y que un gran número de personas haya rechazado, ásperamente, su decisión no es motivo suficiente para temer que el Tribunal Superior de Justicia de Navarra o, en su caso, el Tribunal Supremo vayan a sentirse obligados, a la hora de resolver los recursos, a tener en cuenta ese «clamor social»: tanto uno como otro órgano judicial están servidos por personas experimentadas, conocedoras del derecho que deben aplicar y, se presume, capaces de desarrollar su trabajo al margen de las presiones sociales o políticas que puedan recibir (...)». Presno Linera, M. A. (2018). «Proceso penal y proceso social (A propósito del caso «La Manada»)». El Cronista del Estado Social y Democrático de Derecho, 77, 50-59, 59.

117 STS 344/2019, de 4 de julio de 2019, FJ 1.

118 Ibidem. 
puesto que los miembros del jurado, que son legos, son más vulnerables a la presión mediática y a la presión de sus «amistades» en las redes sociales ${ }^{119}$.

La pretensión de aislar físicamente a los jurados y alejarlos de los medios funcionaba relativamente bien en el mundo material, lo que se complica hoy en día por la facilidad de acceder a equipos móviles con conexión a Internet. La amenaza actualmente se concreta en la posibilidad que los jurados consulten Internet y las redes sociales, durante las sesiones del juicio, para consultar información en general o para buscar fuentes de información que les ayuden a tomar una decisión o en las deliberaciones. En su versión más grave, los jurados podrían llegar a compartir en las redes sociales sus impresiones y opiniones sobre lo que está pasando en el juicio ${ }^{120}$.

Como consecuencia, resulta imprescindible en los países de esa tradición jurídica regular el acceso y uso de las redes sociales durante el juicio, cuyos efectos se extienden tanto a los medios de comunicación como a jueces y jurados; de hecho, algunos tribunales ya han aprobado directrices y normas de policía de vistas que regulan su uso en las salas de justicia ${ }^{121}$. Las medidas que se proponen se concretan en acciones preventivas que viajan desde la mera advertencia a los jurados hasta fuertes sanciones administrativas o penales con claros fines disuasorios ${ }^{122}$. Todo ello como reacción a los primeros casos y sentencias que han llegado al punto de anular los efectos de juicios celebrados sin las debidas garantías ${ }^{123}$. Por su parte, en el Reino Unido se han

119 En este sentido véase Simpler, M. F. (2012). «The Unjust «Web» We Weave: The Evolution of Social Media and Its Psychological Impact on Juror Impartiality and Fair Trials». Law E Psychology Review, 36, 275-296.

120 Pueden consultarse, sobre este particular, los trabajos de Marder, N. S. (2014). «Jurors and Social Media: Is a Fair Trial Still Possible?». Southern Methodist University Law Review, 67, 617-668; Dunn, M. (2011) «Jurors' Use of Social Media during Trials and Deliberations». Report to the Judicial Conference Committee on Court Administration and Case Management, Federal Judicial Center, disponible en Internet: http://www.fjc.gov/public/pdf.nsf/lookup/ (última consulta el 1 de abril de 2020).

121 En el Quebec, la magistratura aprobó unas directrices de uso de dispositivos electrónicos dentro de la sala de audiencias o de vistas, que entró en vigor el 15 de abril del 2013. Esas directrices prohíben taxativamente el uso del Twitter durante la fase oral del juicio, tanto para los periodistas como para el público en general, evitando así el tuiteo en directo, que podría ocasionar no sólo problemas en relación con la seriedad y desarrollo del juicio, sino también en el ámbito de la privacidad y la reputación de los intervinientes. Véase la noticia titulada «Twitter banni des tribunaux du Québec», publicada en el diario La Presse, con fecha de 29 de marzo de 2013, disponible en Internet: http://www.lapresse.ca/le-soleil/ actualites/justice-et-faits-divers/201303/28/01-4635816-twitter-banni-des-tribunaux-du-quebec.php (última consulta el 1 de abril de 2020).

122 Véase Janoski-Haehlen, E. M. (2011). «The Courts Are All A 'Twitter': The Implications of Social Media Use in the Courts». Valparaiso University Law Review, vol. 46, 43, 43-68.

123 Un miembro del jurado del Tribunal Supremo de Arkansas que debía juzgar sobre la culpabilidad o inocencia de un condenado a pena capital en 2010 tuiteó durante la celebración del juicio. Procede señalar que a los miembros del jurado no les está permitido realizar tipo alguno de comunicación sobre el proceso judicial en curso, para evitar que nadie, desde el exterior, pueda afectar o condicionar su decisión sobre el caso. El Tribunal consideró que tal conducta constituye una discusión pública acerca del objeto del proceso si se tiene en cuenta la naturaleza de Twitter como red social y medio de comunicación. Como consecuencia, anuló los efectos del juicio y ordenó celebra uno nuevo, con las 
dictado sentencias condenatorias a jurados por el uso de las redes sociales durante los juicios ${ }^{124}$. Se trata de una problemática que irrumpió con fuerza a principios de 2010 y que ha seguido la misma tónica hasta día de hoy.

Como se observa, no se trata de casos anecdóticos, sino de una tendencia natural, humana, de querer consultar la información y compartirla con amigos a través de las redes, algo especialmente grave en el caso de los jurados legos que, a vueltas parecen actuar sin conocer los efectos y consecuencias penales de alejarse de las normas dictadas por el juez.

Con todo, esta compleja realidad carece prácticamente de virtualidad en nuestro modelo, en el que juicio por jurados está muy limitado ${ }^{125}$. La dimensión intraprocesal del derecho a la presunción de inocencia y la imparcialidad judicial goza de la misma tutela y protección frente a cualquier clase de juicio paralelo, con indiferencia del canal comunicativo en el que este se produzca. El mayor blindaje por parte de los jueces profesionales, también frente al efecto de las redes sociales, convierte en improbables los efectos sobre la imparcialidad judicial ${ }^{126}$. Es en esta misma dirección en la que debemos enmarcar el rechazo por parte de la Audiencia Provincial de Navarra, en el episodio de La Manada, a incorporar en los autos la documentación aportada por parte del letrado acerca del seguimiento online y el volumen de búsquedas sobre el tema en el motor de Google.

Por el contrario, los efectos del juicio paralelo en las redes sociales sí se magnifican en comparación con los juicios mediáticos, puesto que la afectación de los derechos de la personalidad y, por ende, también de la presunción de inocencia en su dimensión extraprocesal, se manifiesta con mayor intensidad. La simple lectura de las etiquetas o hashtags y de los mensajes y memes de las redes sociales en el episodio de La Manada muestran con fuerza los efectos más gravosos para el derecho al honor y la honra de las partes procesales. Ese menoscabo se produce tradicionalmente en los derechos de

debidas garantías. Véase la noticia titulada «Arkansas death row inmate spared by juror's tweet», publicada en el diario The Guardian, con fecha de 9 de diciembre de 2011, disponible en Internet:

http://www.guardian.co.uk/world/2011/dec/09/arkansas-death-row-tweet (última consulta el 1 de abril de 2020).

124 En un interesante trabajo, Azurmendi analiza las dos primeras sentencias condenatorias en Reino Unido, la primera de ellas por desacato de un miembro del jurado que utilizando un pseudónimo se puso en contacto con la acusada a través de la red social Facebook mientras el juicio estaba en marcha; la segunda por un jurado que consultó información a través de Internet y la compartió con el resto de los miembros del jurado. Azurmendi, A. (2014). «Twitter en los juicios: una revolución en la información periodística de tribunales». Correspondencias $\mathcal{E}$ Análisis, 4, 37-62.

125 Las cifras y estadísticas judiciales así lo demuestran. En 2018, se elevaron a la vista del Jurado un total de194 causas con preso y 162 sin preso. Datos extraídos del informe «La Justicia dato a dato», año 2018, del Consejo General del Poder Judicial, disponible en línea:

http://www.poderjudicial.es/stfls/ESTADISTICA/FICHEROS/JusticaDatoaDato/Datos\%20 Anteriores/Justicia\%20Dato\%20a\%20Dato\%202018.pdf (última consulta el 1 de abril de 2020).

126 Es de la misma opinión Guzmán Fluja, V. C. (2018). «Juicios paralelos en las redes sociales y proceso penal». IDP: Revista de Internet, Derecho y Política, 27, 57. 
los acusados, aunque en este episodio, también en los de la víctima ${ }^{127}$, en una suerte de batalla de posicionamientos extremos en pos de cada bando. Hubo acusaciones para todos, y en ocasiones los comentarios fueron agresivos o simplemente cayeron en el insulto; de hecho, se vivieron escenas cercanas al linchamiento. No es de extrañar, entonces, que el TS admitiese que las alegaciones de los recurrentes en el caso de La Manada, relativas al efecto mediático del caso, a las manifestaciones y publicaciones vertidas en redes sociales y a los pronunciamientos del Ministro de Justicia al respecto, «en todo caso afectarían a la dimensión extraprocesal de la presunción de inocencia» ${ }^{128}$, cuya lesión efectiva deberá valorar el juez competente que conozca en el caso que se formulen reclamaciones en tal sentido.

Parte de la doctrina se ha referido a la dimensión extraprocesal de la presunción de inocencia como el derecho a la «reputación de inocencia», que además de la dimensión privada que despliega efectos frente a particulares o medios de comunicación, cuenta con una dimensión pública que despliega efectos frente a los actos de los poderes públicos que lesionen el buen nombre de quien ostenta la presunción de inocencia constitucionalmente garantizada ${ }^{129}$.

Las razones que explican la afectación mayor a los derechos de la personalidad son las que comprenden en su magnitud los elementos del espacio comunicativo virtual. La perennidad de la información en la web — nada se borra ni olvida por defecto-, su efecto multiplicador y la trampa que esconden los algoritmos de las redes sociales, facilitan la estigmatización social y la persecución de los individuos. El papel de los medios de comunicación es relevante, como actores principales que son dentro de las redes sociales, pero además hay que sumar el efecto exponencial de otros actores y también la participación de los cibernautas individualmente considerados.

No es menos cierto que el afectado puede reaccionar contra el daño sufrido por la vía de reclamar por vulneración del derecho al honor, a la intimidad o a la propia imagen. El ordenamiento jurídico presenta así instrumentos que permiten perseguir a los autores de la intromisión ilegítima o de la conducta típica; sin embargo, no hay todavía elementos específicos que atiendan a la significación cualitativa y cuantitativa del daño que se causa a través de las redes sociales ${ }^{130}$. Por ello proliferan empresas que se dedican al borrado del pasado digital y que pueden llegar a pedir cantidades ingentes de dinero dependiendo del perfil del afectado y del impacto en la red.

Las posibilidades de tutela del afectado frente a los responsables de la gestión de las redes sociales, por su parte, parecen más que reducidas. Cualquier intento de retirada de contenidos, etiquetas o foros online debe tener como punto de partida una decisión judicial que haya ponderado los derechos en juego, por tratarse de derechos

127 La víctima de la agresión se vio sometida a un escudriñamiento absoluto de su vida, acentuado por el debate en las redes sociales. Véase Planchadell Gargallo, A. (2019). «Publicidad del proceso e intimidad de la víctima..., cit., 150-171.

128 STS 344/2019, de 4 de julio de 2019, FJ 1.

129 Rodríguez, A. (2016). El honor de los inocentes..., cit, 571 y ss.

130 A este mismo corolario llega Guzmán Fluja, V. C. (2018). «Juicios paralelos..., cit., 62. 
fundamentales, y cabe recordar que la instantaneidad es una de las características de la web, lo que contrasta con el ritmo de la justicia. Las medidas dirigidas a los gestores de la red social para exigir la retirada de una etiqueta por ilicitud manifiesta o la suspensión de cuentas concretas contra los usuarios que contribuyan a generar y alimentar juicios paralelos tienen poco recorrido porque, de un lado, siempre llegarán tarde en el plano temporal, y del otro, cabe recordar que se puede viralizar ${ }^{131}$ una etiqueta igual de lesiva con éxito o crear una cuenta en cuestión de cinco minutos.

Una opción bien distinta sería requerir a los gestores de las redes sociales para que activen protocolos de forma proactiva con el fin de detectar de forma preventiva la creación de juicios paralelos, para minimizar su impacto o incluso actuar con celeridad de forma represiva una vez creados ${ }^{132}$. De hecho, esto sucede con frecuencia cuando el contenido publicado infringe las políticas internas de las redes sociales, que cubren muchos escenarios, como la protección de derechos de autor, de los menores y contra la explotación sexual infantil, de las marcas comerciales, de la desnudez no consensuada, de contenidos de carácter delicado, de conductas de incitación al odio, de la suplantación de identidad, etc. No se trata, en ningún caso, de establecer una censura indirecta a través del gestor de la red social, sino más bien de reconocer el derecho a contextualizar la información y establecer un límite a la descontextualización, atenuando así en cierto modo los efectos de la viralización y el impacto de la desinformación en la opinión pública. Se trataría de aplicar reglas parecidas para detectar y debilitar los llamados juicios paralelos, aunque eso seria como pedir al gestor de la red social que desaproveche un tema de interés periodístico que está llamado a convertirse en tendencia, o lo que es lo mismo, que renuncie a sacar el máximo partido a su algoritmo egoísta en relación con una temática que aúna los elementos que consiguen mantener más cibernautas activos durante más tiempo dentro de la aplicación de la red social.

Para la determinación de las consecuencias jurídicas resultaría fundamental además atender al papel que han desempeñado los diferentes actores — medios de comunicación, agencias gubernamentales, partidos políticos, élites económicas o digitales, el público en general y los gestores de las redes sociales, entre otros- en el marco del juicio paralelo acontecido en la red social. La clave pasa por diferenciar los intermediarios de los editores, distinguir la responsabilidad de los actores profesionales

131 Un interesante estudio sobre los desafíos que la desinformación plantea para las garantías constitucionales de la opinión pública en Internet, principalmente en las redes sociales, puede encontrarse en el trabajo de García Sanz, que contiene propuestas para debilitar el impacto nocivo mediante el derecho al contexto de la información. Véase García Sanz, R. M. (2019). «La difícil relación del instituto de la opinión publica y los procesos de comunicación publica en Internet: la desinformación desafiando las garantías constitucionales». Revista de Derecho Político, 106, 77-104.

132 Una idea expresada también por Guzmán Fluja, que propone como alternativa una mayor implicación de los responsables de gestión y uso de las redes sociales para activar mecanismos preventivos $\mathrm{y}$, en su caso, represivos. Ibídem. 
respecto a la de los usuarios y estudiar la naturaleza de los mensajes en el caso concreto $^{133}$.

Todo lo anterior sólo es esgrimible en aquellos casos más graves, cuya afectación al honor o a la «reputación de inocencia» no puede encontrar sustento, protección o amparo alguno dentro de las libertades informativas ${ }^{134}$, cuyo contenido se aleja del interés público informativo ${ }^{135}$, cae en el insulto o se enmarca en las prácticas deleznables y dentro de la definición de juicio paralelo que hemos empleado a lo largo de este trabajo. Por el contrario, las críticas a las resoluciones judiciales y a la actuación de la justicia, también aquellas que pueden llegar a molestar u ofender a buena parte de la judicatura, deben admitirse sin mayores problemas porque contribuyen a mantener el necesario equilibrio entre las divisiones saludables y los acuerdos necesarios entre el juzgador, que no opera en el vacío, y los distintos actores político-sociales ${ }^{136}$.

\section{CONCLUSIONES.}

Primera. - Los juicios paralelos han sido una constante en nuestro país a lo largo de las tres últimas décadas. Podemos referirnos a ello como una patología informativa cuya solución no parece del todo fácil. Desde el juicio de las niñas de Alcácer muchas han sido las propuestas para mitigar, reducir o eliminar los efectos de los juicios mediáticos, si bien se han mostrado ineficaces como demuestra la práctica habitual de los programas de (des)información judicial. Los mecanismos de autorregulación de los medios de comunicación no han mostrado efectividad alguna, incluso los que llevan aparejadas sanciones concretas.

Segunda. - La irrupción de Internet y las redes sociales han revolucionado por completo el paradigma comunicativo. La arquitectura en red, las facilidades de acceso y almacenamiento de la información, la velocidad e inmediatez, son factores propios

133 Véase García Sanz, R. M. (2019). «La difícil relación..., cit, 102.

134 Nótese que a lo largo del trabajo nos hemos referido a las libertades informativas en general, si bien hubiera resultado interesante diferenciar cada una de las libertades — libertad de información y libertad de expresión - con el detalle de sus diferentes características jurídicas y las garantías constitucionales que deben satisfacer respectivamente. Excede a los límites de este trabajo un análisis en profundidad, pero conviene resaltar que para el estudio del caso concreto se deben diferenciar los distintos elementos subjetivos, objetivos y la heterogeneidad de los espacios de comunicación digital, para la aplicación diferenciada de la normativa. Como bien señala Rosa María García Sanz se debe «diferenciar el régimen jurídico de las libertades de información y expresión (y la diferente naturaleza de mensajes); distinguir la exigibilidad y responsabilidad de los profesionales respecto a la de los usuarios; y determinar un régimen diferenciado de los intermediarios respecto a los editores». García Sanz, R. M. (2019). «La difícil relación..., cit, 102 .

135 Nos referimos una vez más a los casos incardinables en el infoentrenemiento propio de la prensa o los programas dedicados al cotilleo y al espectáculo judicial, a los que se debería aplicar un estándar particularmente reducido de protección jurídica, y ello como consecuencia de su especial sujeción a normas procesales o de su escaso valor para el debate público stricto sensu.

136 Véase Chayes, A. (1975). «The Role..., cit. 
de Internet que combinados con el algoritmo «egoísta» de las redes sociales contribuyen a magnificar los efectos de la desinformación. Un escenario ideal para la posverdad y las fake news. Una nueva extensión para los juicios paralelos que se magnifican sin lugar a duda en los entornos digitales, en los que también participan activamente los medios de comunicación social. El núcleo del problema de los juicios paralelos en las redes sociales, así como sucede con la desinformación, radica en los mensajes que no son aptos conforme a la garantía institucional y en la falta de auténticos profesionales de la información que se impongan en ese escenario.

Tercera. - La doctrina jurisprudencial tanto del TC como del TEDH ha matizado que los juicios mediáticos no afectan, por lo general, al derecho a un juicio justo, a un juez imparcial y a la presunción de inocencia en su dimensión intraprocesal. Los jueces profesionales están capacitados y preparados para asumir la presión de la opinión pública y de los medios de comunicación, incluso cuando esta se vehicula a través de un ejercicio inadecuado y espurio de las facultades derivadas de la libertad informativa. Esta premisa puede y debe aplicarse a todos los juicios paralelos sin necesidad de diferenciar los analógicos de los digitales, puesto que la capacitación y formación de los miembros del Poder Judicial es la misma con indiferencia de los efectos o expansión del juicio mediático, tal y como ha quedado demostrado con el estudio del caso de La Manada. Una tesis que no se puede defender, por el contrario, en el caso de juicios por jurados, por razones obvias. Por ello, en perspectiva comparada se ha regulado el acceso y uso de las redes sociales durante el juicio, cuyos efectos se extienden tanto a los medios de comunicación como a jueces y jurados. Más concretamente, el sistema anglosajón ha reaccionado en virtud de las normas de policía de vistas a los efectos de regular lo que se no se puede difundir sobre las mismas.

Cuarta. - La diferenciación entre el juicio paralelo vivido en el mundo material y el digital sí resulta necesaria, en cambio, cuando hablamos de los efectos que se proyectan sobre la presunción de inocencia en su dimensión extraprocesal y sobre el honor, así como los demás derechos de la personalidad vinculados a la dignidad humana. La magnificación del juicio digital incide en la amplificación de los efectos nocivos de la desinformación. El daño que ocasiona el veredicto o condena online resulta irreparable por cuanto estigmatiza socialmente al afectado —investigados, víctimas, testigos, etc. - y lo persigue de por vida.

Por su parte, el ejercicio del derecho de rectificación no puede suplir acciones tan graves como la presencia de un juicio paralelo, lo que en el entorno digital deviene aún más ineficaz por la imposibilidad, en sentido estricto, de poder publicar una rectificación en redes sociales con relevancia similar a aquella que pretende rectificar. La falta de recursos de los afectados por el juicio paralelo es palmaria, y se evidencia bien en el caso de La Manada, en el que uno de los abogados defensores aportó datos estadísticos con detalle del volumen de búsquedas en Google sin que ello pueda ser admitido como prueba y sin que vaya a tener, a la postre, consecuencia jurídica alguna; cuando paralelamente, los magistrados, son conscientes del evidente juicio paralelo que se está produciendo extramuros. 
Quinta. - Las libertades informativas juegan un papel fundamental en una sociedad democrática, por ello merecen una especial tutela que incluso opera como causa de exención ante conductas delictivas efectuadas por los medios de comunicación —artículo 20.7 del Código Penal— , siempre y cuando se respete la diligencia y ética informativa. Procede recordar en este sentido que el juicio paralelo se sitúa a las antípodas de esa diligencia, lesionado también el derecho del público a saber, al tratarse de un ejercicio adulterado y espurio que no puede estar cubierto de modo alguno por las facultades derivadas de la libertad de información y comunicación. De hecho, en esa clase de juicios mediáticos, no existe información en sentido abstracto, pues no se respetan ninguna de las garantías de la diligencia informativa.

Sexta. - Que no exista una solución fácil no significa que constituya una aporía. Conviene en este sentido hacer un esfuerzo de reflexión para superar el estadio de análisis y diagnóstico de la cuestión y proponer soluciones concretas.

Recuérdese en este sentido que los juicios paralelos, también en su versión digital, son creados en parte por la acción y retroalimentación de los medios de comunicación, aunque son muchos los actores que tratan de aprovecharse del algoritmo de las redes sociales en su lucha por la audiencia. Reconocer en este ámbito la responsabilidad de los gestores de las redes sociales y diferenciar el régimen entre el intermediario y el editor del mensaje podría resultar de gran utilidad. Cabría además explorar la posibilidad de aceptar el derecho a contextualizar la información que se difunde en las redes y establecer límites a la descontextualización, mitigando los efectos de la viralización y el impacto de la desinformación en la opinión pública. Una medida razonable pasa por exigir una mayor implicación de los responsables de gestión de las redes sociales para activar protocolos y mecanismos preventivos que, por otro lado, se han mostrado eficientes en otros campos como la persecución de contenidos protegidos por derechos de autor.

Para los casos más graves, protagonizados en redes por los mismos responsables de la prensa amarillenta o de los programas de la llamada telebasura, un incremento de la respuesta de naturaleza penal sería realmente deseable, con el fin de incorporar tipos específicos para profesionales de la información o periodistas en caso de desinformación o posverdad judicial.

Por su parte, la vía civil, de reparación de daños ilegítimos, debería tener siempre en consideración el efecto exponencial o multiplicador de la red de redes para poder calcular el quantum indemnizatorio.

No sería desdeñable optar por una nueva normativa que regule el secreto sumarial, que como hemos visto a lo largo del trabajo presenta una protección desigual en función de si se trata del secreto externo o interno, este último decretado expresamente por el instructor. Si la regla general en la fase de investigación es el secreto, este debería respetarse y los mismos mecanismos y repuesta penal que protege el secreto interno podrían servir para garantizar el secreto externo del sumario. También un cambio normativo debería simplificar y unificar criterios respecto a la publicidad de las sentencias. En este ámbito, la regla general es la publicidad relativa, ofreciendo al 
público lo esencial pero no lo accesorio — datos personales_- luego no tiene sentido que a los medios de comunicación se les facilite el texto de la sentencia íntegro, con los detalles y datos personales al descubierto, tal y como sucedió en el caso de La Manada, revelando la identidad de la víctima.

Séptima. - En 1995, en una viñeta cómica del New York Times, un perro invitaba a otro a navegar en Internet bajo el lema «nadie sabe que eres un perro». Hoy en día, por el contrario, nadie es anónimo en la navegación en la red. La anécdota bien nos sirve para subrayar que no debemos resignarnos a considerar el juicio paralelo, en general, y en los entornos digitales, en particular, como un mal necesario de una sociedad democrática. También la red puede cambiar y no es aceptable afirmar que «no se pueden poner puertas al campo». El Derecho puede y debe aspirar a regular todos los entornos, también el digital, a efectos de mitigar los excesos de la desinformación judicial e infoxicación hiperventilada.

Title:

Trials by social media in the Digital Age. An old acquaintance in a new sphere

Summary:

I. INTRODUCTION: FUNDAMENTAL RIGHTS IN THE DIGITAL SCENARIO. II. 'TRIALS BY MEDIA' PROBLEMS: THREE DECADES OF DEBATE. 1. TRIALS BY PRESS, FREEDOM OF SPEECH AND THE RIGHT TO A FAIR AND PUBLIC TRIAL. a) During Pre-Trial Stage. b) Trial. c) Judgments Publicity. 2. EFFECTS OF MISINFORMATION ON INDIVIDUAL RIGHTS. III. TRIALS BY SOCIAL MEDIA: LA MANADA CASE. 1. MEDIA COVERAGE. a) Traditional Media and TV. b) Digital Media and Social Networks. 2. EFFECTS OF MISINFORMATION ON INDIVIDUAL RIGHTS. IV. CONCLUSIONS.

\section{Resumen:}

En el presente artículo se estudia la patología informativa que suponen los llamados juicios paralelos, así como sus efectos para los derechos y garantías jurídico-constitucionales. El problema, en los últimos años, lejos de disiparse, parece que se enquista y magnifica, al alcanzar nuevas cotas de audiencia y seguimiento gracias a las características del proceso comunicativo de las redes sociales de Internet. 
El trabajo parte así del estudio de las transformaciones que las nuevas tecnologías han supuesto para el proceso de comunicación pública y los derechos fundamentales, entre las que destaca el derrumbe del modelo de crítica pública y la liquidación de la institución de la opinión pública libre en la sociedad digital, en la que predomina la desinformación e infoxicación en sus múltiples facetas — posverdad, fake news, conocimiento superficial, bots, etc.- .

A continuación, se analizan los efectos de los juicios paralelos sobre los derechos fundamentales y el proceso penal, tanto en su versión analógica como en la digital. Con ello se pretende observar si el mayor seguimiento y retroalimentación que se produce en el contexto digital se traduce también en una mayor afectación de los derechos en juego, lo que se ejemplifica en un caso reciente de relevancia mediática («La Manada»).

Finalmente, se formulan propuestas para paliar la situación y salir de la encrucijada.

\begin{abstract}
:
This article studies the issues that 'Trials by Media' arise, as well as its effects on fundamental rights and process guarantees. The problem, in recent years, far from dissipating, seems to become entrenched and magnified, reaching new levels of audience thanks to the social networks structure and net algorithms.

The work thus starts studying the transformations that ICT have brought both to the process of public communication and fundamental rights, among which appears the collapse of the model of public criticism and the end of the institution of free public opinion in the digital society, where disinformation prevails in its many faces — post-truth, fake news, superficial knowledge, etc.-

Therefore, we analyze the effects of social media trials on fundamental rights and the criminal process. We expect to show if the greater follow-up and feedback that occurs in the digital scenario also translates into a greater affectation of the rights, which is exemplified in a recent case of public relevance («La Manada»).

Finally, proposals are made to ease the situation and get out of the crossroad.
\end{abstract}

\title{
Palabras Clave:
}

Libertades informativas; redes sociales; Internet; juicios paralelos; derecho al honor; presunción de inocencia; derecho a un juez imparcial; medios de comunicación; derecho digital.

\section{Keywords:}

Freedom of Speech; Social Networks; Internet; Trials by Media; Reputation; Presumption of Innocence; Right to a Fair Trial; Media; Digital Law. 